\title{
An intercomparison of tropical cyclone best-track products for the southwest Pacific
}

\author{
Andrew D. Magee ${ }^{1}$, Danielle C. Verdon-Kidd ${ }^{1}$, and Anthony S. Kiem ${ }^{2}$ \\ ${ }^{1}$ Environmental and Climate Change Research Group (ECCRG), School of Environmental and Life Sciences, \\ Faculty of Science and Information Technology, The University of Newcastle, Callaghan, NSW, 2308, Australia \\ ${ }^{2}$ Centre for Water, Climate and Land (CWCL), Faculty of Science and Information Technology, \\ The University of Newcastle, Callaghan, NSW, 2308, Australia
}

Correspondence to: Andrew D. Magee (andrew.magee@uon.edu.au)

Received: 4 February 2016 - Published in Nat. Hazards Earth Syst. Sci. Discuss.: 19 February 2016

Revised: 25 May 2016 - Accepted: 25 May 2016 - Published: 16 June 2016

\begin{abstract}
Recent efforts to understand tropical cyclone (TC) activity in the southwest Pacific (SWP) have led to the development of numerous TC databases. The methods used to compile each database vary and are based on data from different meteorological centres, standalone TC databases and archived synoptic charts. Therefore the aims of this study are to (i) provide a spatio-temporal comparison of three TC best-track (BT) databases and explore any differences between them (and any associated implications) and (ii) investigate whether there are any spatial, temporal or statistical differences between pre-satellite (1945-1969), postsatellite (1970-2011) and post-geostationary satellite (19822011) era TC data given the changing observational technologies with time. To achieve this, we compare three besttrack TC databases for the SWP region $\left(0-35^{\circ} \mathrm{S}, 135^{\circ} \mathrm{E}-\right.$ $120^{\circ} \mathrm{W}$ ) from 1945 to 2011 : the Joint Typhoon Warning Center (JTWC), the International Best Track Archive for Climate Stewardship (IBTrACS) and the Southwest Pacific Enhanced Archive of Tropical Cyclones (SPEArTC). The results of this study suggest that SPEArTC is the most complete repository of TCs for the SWP region. In particular, we show that the SPEArTC database includes a number of additional TCs, not included in either the JTWC or IBTrACS database. These SPEArTC events do occur under environmental conditions conducive to tropical cyclogenesis (TC genesis), including anomalously negative $700 \mathrm{hPa}$ vorticity (VORT), anomalously negative vertical shear of zonal winds (VSZW), anomalously negative $700 \mathrm{hPa}$ geopotential height (GPH), cyclonic (absolute) $700 \mathrm{hPa}$ winds and low values of absolute vertical wind shear (EVWS). Further, while changes
\end{abstract}

in observational technologies from 1945 have undoubtedly improved our ability to detect and monitor TCs, we show that the number of TCs detected prior to the satellite era (19451969) are not statistically different to those in the postsatellite era (post-1970). Although data from pre-satellite and pre-geostationary satellite periods are currently inadequate for investigating TC intensity, this study suggests that SPEArTC data (from 1945) may be used to investigate longterm variability of TC counts and TC genesis locations.

\section{Introduction}

Recently, there has been a concerted effort towards understanding the relationships between climatic variability and the spatio-temporal variability of tropical cyclone (TC) activity in the southwest Pacific (SWP; $0-35^{\circ} \mathrm{S}, 135^{\circ} \mathrm{E}-120^{\circ} \mathrm{W}$ ) and smaller regions within the Pacific basin (Kuleshov et al., 2008, 2010; Chand and Walsh, 2009, 2010; Dowdy et al., 2012; Chand et al., 2013; Diamond et al., 2013; Diamond and Renwick, 2015a, b). In order to achieve this, it has been necessary to develop quality controlled TC databases that provide information about TC frequency, intensity, onset location and subsequent TC tracks (Chu et al., 2002; Knapp and Kruk, 2010; Kuleshov et al., 2010; Diamond et al., 2012). As a result, several SWP TC databases exist including: the Joint Typhoon Warning Center (JTWC) best-track database, the International Best Track Archive for Climate Stewardship (IBTrACS) and the Southwest Pacific Enhanced Archive of Tropical Cyclones (SPEArTC), among others explored fur- 
ther in Sect. 2.1. Best-track (BT) data refer to the estimates of position and intensity at intervals of $6 \mathrm{~h}$ for the duration of a TC event. Each data set draws on data from meteorological centres, standalone TC databases and archived synoptic charts to develop their collection of TC events (further detailed in Sect. 2.1). Such quality controlled, homogenous databases are necessary for producing meaningful conclusions from TC modelling or climate attribution studies (Dowdy et al., 2012). However, given that multiple databases exist, a study of the similarities and differences between each data set and an assessment of which one(s) is (are) the most complete and/or accurate is urgently needed.

In addition to the choice of TC data set, questions have been raised over the accuracy and therefore usefulness of TC observations before 1969 (i.e. prior to the inclusion of satellite-derived information on TCs) (Holland, 1981). In the SWP region, these concerns have primarily been based on the early work of Holland (1981), who used a collection of TC events from the Australasian region $\left(105-165^{\circ} \mathrm{E}\right.$, $0-32^{\circ} \mathrm{S}$ ) compiled by Lourensz (1977) to quantify possible errors and/or missing data from 1909 through to 1979 . Holland (1981) studied a number of parameters, including TC occurrence, coastal crossings, location and intensity and found that TC data were more reliable closer to the coast (within $500 \mathrm{~km}$ ) for all parameters studied. Importantly, Holland (1981) noted a change in the quality of TC observations over time. In particular, from 1909 to 1959, the study estimated that up to $50 \%$ of TCs were missing from the Lourensz (1977) database. An increase in reliability of the database was observed from 1959 (up to $30 \%$ missing), as a result of the introduction of radar observations. The most substantial improvement in the quality of TC observations (up to $15 \%$ missing) occurred with the introduction of routine-enhanced observational technologies from 1969, termed the "satellite-era" (Kuleshov, 2002; Webster et al., 2005). Importantly, the findings of Holland (1981) have been used as a basis for limiting TC climate analysis studies to the "post-satellite" era from 1969 onwards (Chand and Walsh, 2010; Kuleshov et al., 2010; Wijnands et al., 2014; Diamond and Renwick, 2015b). Some studies have constrained this further, using TC data from 1982 only (Kuleshov et al., 2008; Dowdy and Kuleshov, 2012; Dowdy, 2014; Kossin et al., 2014), the period of continuous and routine geostationary satellite observations for the region, to allow for reliable intensity estimates (Dvorak, 1984; Klotzbach, 2006). However, this temporal constraint makes it difficult to rigorously assess any long-term trends in TC activity and prevents the study of potential impacts of multi-decadal process such as the Interdecadal Pacific Oscillation (IPO) on TC activity. As such, a contemporary analysis revisiting the usefulness of pre-satellite TC data for the SWP is urgently needed.

The aims of this study are to (i) provide a spatio-temporal comparison of three TC BT databases and explore any differences between them (and any associated implications) and (ii) investigate whether there are any spatial, temporal or sta- tistical differences between pre-satellite (1945-1969), postsatellite (1970-2011) and post geostationary satellite (19822011) era TC data given the changing observational technologies with time.

\section{Data}

\subsection{Review of best-track databases}

Many records of TC tracks exist for the SWP (Table 1; Visher, 1925; Giovannelli, 1952; Kerr, 1976; Lourensz, 1977, 1981; Revell, 1981; Chu et al., 2002; Knapp et al., 2010; Diamond et al., 2012), which have been collated from irregular ship reports, land observations, TC reconnaissance missions, geosynchronous satellite observations and best-track reanalyses (summarised in Table 2). In addition to many different data sources, inconsistencies between TC databases may be attributed to changes in observational technologies (Chu et al., 2002), changes in data analysis techniques over time and changes in the definition of TCs (Knapp and Kossin, 2007). Interagency differences may also exist, such as different wind speed averaging methods (Knapp and Kruk, 2010). Spatially, the accuracy of tropical cyclogenesis (TC genesis) points and TC tracks may be questionable, again due to changes in observational technologies and the subjective nature of defining best tracks (see Guard et al., 1992 on difficulties of track forecasting). Each data set also varies in spatial and temporal coverage.

Of the TC databases listed in Table 1, three were chosen for further analysis based on their (i) comparable geographical extent, which for the purposes of this investigation has been defined as $0-35^{\circ} \mathrm{S}, 135^{\circ} \mathrm{E}-120^{\circ} \mathrm{W}$ (Fig. 1); (ii) overlapping time period, 1945-2011, and (iii) use in peer-reviewed literature. Where spatial and temporal values exceed these ranges, databases were trimmed to ensure homogeneity. The study domain of the SWP region spans numerous World Meteorological Organisation (WMO) TC Regional Specialised Meteorological Centres (RSMCs) and Tropical Cyclone Warning Centers (TCWCs). The following provides a review of the BT databases used in this investigation.

The Joint Typhoon Warning Center (JTWC) best-track database, established in 1959, initially only included the eastern North Pacific as its area of responsibility (AOR). With the goal of preventing loss of life and property (Guard et al., 1992), the JTWC AOR was then extended in October 1980 to include the Southern Hemisphere (west of $180^{\circ}$ to the east coast of Africa). Since then, the BT archive for the SWP has been extended from 1945 to the present day and encompasses $135^{\circ} \mathrm{E}-120^{\circ} \mathrm{W}$ of the South Pacific basin. Three sources have been used to compile the JTWC database (Table 1). Its use in TC-related studies are widespread (e.g. Klotzbach, 2006; Chand and Walsh, 2009, 2010). 
Table 1. Review of tropical cyclone databases for the southwest Pacific.

\begin{tabular}{|c|c|c|c|c|c|c|c|c|c|}
\hline \multirow[t]{2}{*}{ Product } & \multirow[t]{2}{*}{ Basin } & \multicolumn{2}{|c|}{ Latitude } & \multicolumn{2}{|c|}{ Longitude } & \multirow{2}{*}{ Temporal } & \multirow{2}{*}{ Sources (Not Exhaustive) } & \multicolumn{2}{|c|}{$\begin{array}{l}\text { Extent suitable for } \\
\text { this study? }\end{array}$} \\
\hline & & Min & Max & Min & Max & & & Spatial & Temporal \\
\hline \multirow{3}{*}{$\begin{array}{l}\text { Joint Typhoon Warning } \\
\text { Centre (JTWC) } \\
\text { (Chu et al. 2002) }\end{array}$} & $\begin{array}{c}\text { S. } \\
\text { Hemisphere }\end{array}$ & -90 & 0 & 15 & -110 & \multirow{3}{*}{$1945-2013$} & \multirow{3}{*}{$\begin{array}{l}\text { - A Fleet Numerical Meteorology and } \\
\text { Oceanography Center (FNMOC) database } \\
\text { - Automated TC Forecasting System (ATCF) } \\
\text { database (Sampson and Schrader 2000) }\end{array}$} & \multirow{3}{*}{$\checkmark$} & \multirow{3}{*}{$\checkmark$} \\
\hline & $\begin{array}{l}\text { N. Indian } \\
\text { Ocean }\end{array}$ & 0 & 90 & 20 & 100 & & & & \\
\hline & $\begin{array}{l}\text { W. North } \\
\text { Pacific }\end{array}$ & 0 & 90 & 90 & 180 & & & & \\
\hline \multirow{7}{*}{$\begin{array}{l}\text { International Best-Track } \\
\text { Archive for Climate } \\
\text { Stewardship (IBTrACS) } \\
\text { (Knapp et al. 2010) }\end{array}$} & N. Indian & 0 & 90 & 30 & 100 & \multirow{7}{*}{$1842-2013$} & $\begin{array}{l}\text { - National Climatic Data Center TD9636 dataset } \\
\text { - Australian Bureau of Meteorology (BoM) }\end{array}$ & \multirow{7}{*}{$\checkmark$} & \multirow{7}{*}{$\checkmark$} \\
\hline & W. Pacific & 0 & 90 & 100 & 180 & & & & \\
\hline & E. Pacific & 0 & 90 & 180 & Variable & & $\begin{array}{l}\text { - Japan Meteorological Agency (RSMC Tokyo) } \\
\text { - Meteo-France (RSMC La Reunion) }\end{array}$ & & \\
\hline & N. Atlantic & 0 & 90 & Variable & 30 & & $\begin{array}{l}\text { - Met Service of NZ (TCWC Wellington) } \\
\text { - NOAA's Central Pacific Hurricane Center } \\
\text { (RSMC Honolulu) }\end{array}$ & & \\
\hline & S. Indian & -90 & 0 & 10 & 135 & & $\begin{array}{l}\text { - NOAAs National Hurricane Centre (NHC) } \\
\text { - China Met Administration's Shanghai Typhoon }\end{array}$ & & \\
\hline & S. Pacific & -90 & 0 & 135 & -70 & & $\begin{array}{l}\text { - Hong Kong Observatory (HKO) } \\
\text { - U.S. Department of Defense - Joint Typhoon }\end{array}$ & & \\
\hline & S. Atlantic & -90 & 0 & -70 & 10 & & - C. Neumann's Southern Hemisphere Data & & \\
\hline $\begin{array}{c}\text { Southwest Pacific } \\
\text { Enhanced Archive of } \\
\text { Tropical Cyclones } \\
\text { (SPEArTC) } \\
\text { (Diamond et al. 2012) }\end{array}$ & SW Pacific & -65 & -5 & 135 & -120 & $1840-2014$ & $\begin{array}{l}\text { - Joint Typhoon Warning Centre (JTWC) } \\
\text { - BoM } \\
\text { - IBTrACS } \\
\text { - RSMCs Nadi and TCWC Wellington } \\
\text { - Visher (1925) } \\
\text { - TC tracking maps from Fiji, New Caledonia, } \\
\text { New Zealand, Tonga, Solomon Islands and } \\
\text { Vanuatu }\end{array}$ & $\checkmark$ & $\checkmark$ \\
\hline $\begin{array}{c}\text { Australian Bureau of } \\
\text { Meteorology National } \\
\text { Climate Centre (BOM } \\
\text { NCC) } \\
\text { (Trewin 2008) }\end{array}$ & $\begin{array}{l}\text { Australian } \\
\text { Region/SW } \\
\text { Pacific }\end{array}$ & -30 & -5 & 90 & 160 & $1907-2009$ & $\begin{array}{l}\text { - Incorporates Lourensz (1981) and Coleman } \\
\text { (1971) data }\end{array}$ & $\mathrm{x}$ & $\checkmark$ \\
\hline $\begin{array}{l}\text { BoM Database } \\
\text { (Lourensz 1981) }\end{array}$ & $\begin{array}{l}\text { Australian } \\
\text { Region/SW } \\
\text { Pacific }\end{array}$ & -32 & -5 & 105 & 165 & 1909-1980 & - BoM & $\mathrm{x}$ & $\mathrm{x}$ \\
\hline $\begin{array}{l}\text { BoM Database } \\
\text { (Coleman 1971) }\end{array}$ & $\begin{array}{l}\text { Australian } \\
\text { Region/SW } \\
\text { Pacific }\end{array}$ & -30 & -5 & 105 & 165 & 1909-1969 & - BoM & $\mathrm{x}$ & $\mathrm{x}$ \\
\hline $\begin{array}{l}\text { Woodside Energy, Ltd } \\
\text { (WEL) } \\
\text { (Harper et al. 2008) }\end{array}$ & $\begin{array}{l}\text { Australian } \\
\text { Region }\end{array}$ & -30 & -5 & 90 & 160 & $1969-2001$ & - BoM and TCWC Wellington & $\mathrm{x}$ & $\mathrm{x}$ \\
\hline $\begin{array}{l}\text { New Zealand } \\
\text { Meteorological Service } \\
\text { (Kerr 1976) }\end{array}$ & SW Pacific & -30 & 0 & 150 & -150 & 1939-1969 & $\begin{array}{l}\text { - New Zealand Meteorological Service } \\
\text { - BoM } \\
\text { - Met services of: New Caledonia, Fiji, French } \\
\text { Polynesia and Western Samoa }\end{array}$ & $\mathrm{x}$ & $\mathrm{x}$ \\
\hline
\end{tabular}

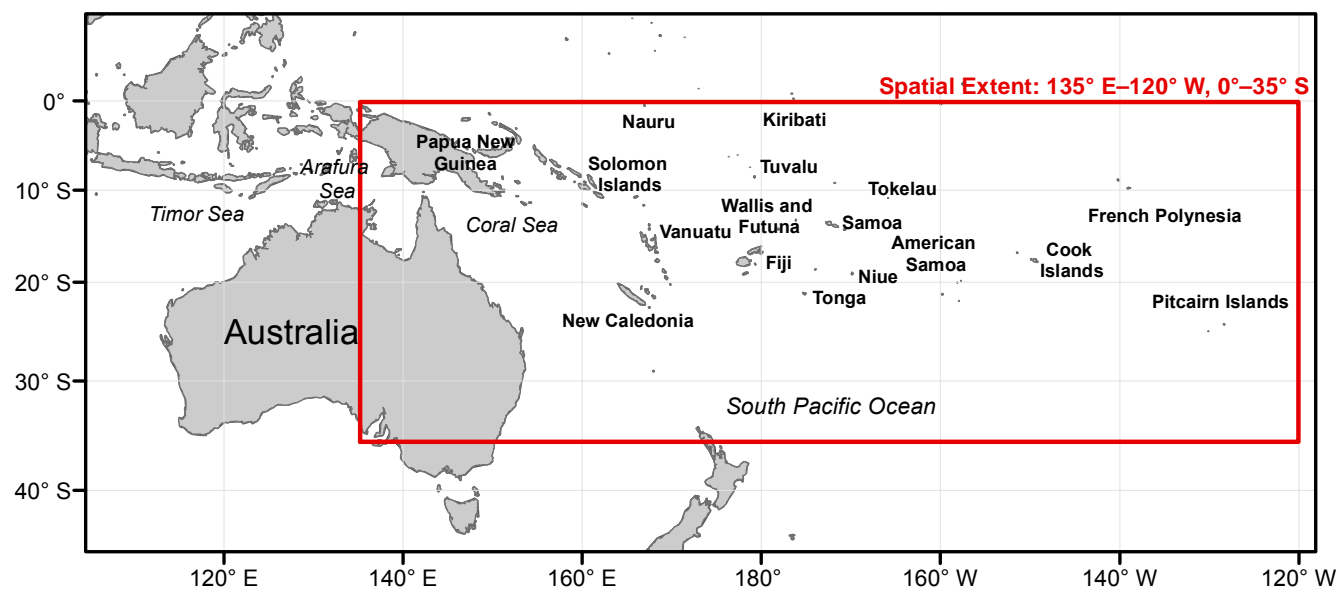

Figure 1. Study area of the southwest Pacific (SWP) $\left(0-35^{\circ} \mathrm{S}, 135^{\circ} \mathrm{E}-120^{\circ} \mathrm{W}\right)$. 
Table 2. Changes in TC observational technologies from 1940 (adapted from Chu et al., 2002).

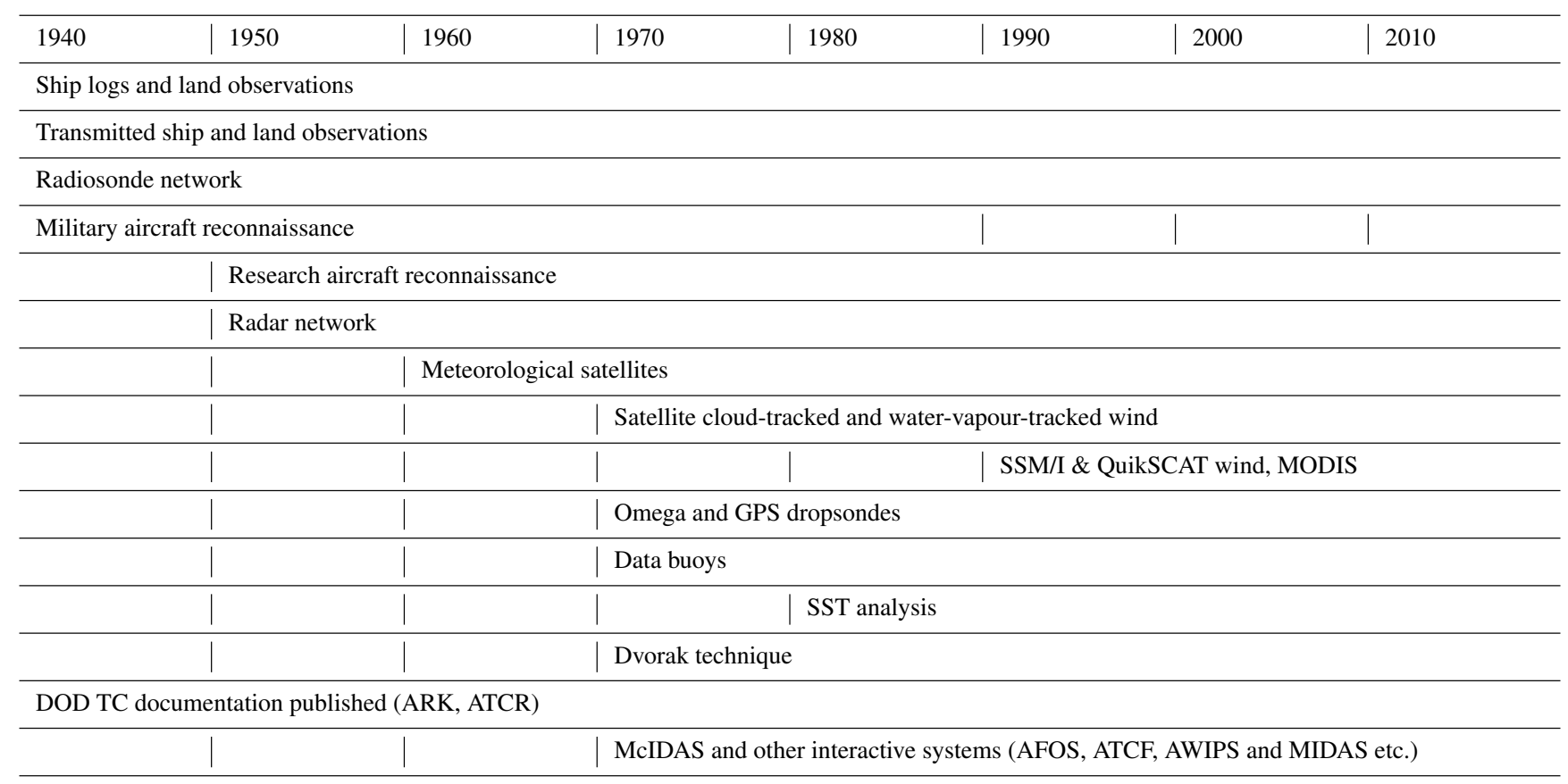

The International Best Track Archive for Climate Stewardship (IBTrACS), conceived and developed by National Oceanic and Atmospheric Administration's National Climatic Data Center is the most complete global repository of TC BT data (Knapp et al., 2009) and has been adopted by the World Meteorological Organization's Tropical Cyclone Programme as its TC BT standard. Extending back to 1842 , IBTrACS collates BTs from a number of forecast centres and meteorological agencies (Table 1). Where duplicate storms occur between two or more sources, the average location at each 6-hour interval is taken (Kruk et al., 2010). A study comparing IBTrACS with JTWC, identified 109 more named storms in IBTrACS compared to JTWC (Knapp and Kruk, 2010), with the authors citing differences in intensity or operational procedures for the mismatch. Two versions of the IBTrACS database currently exist: (i) IBTrACS_ALL which contains all RSMC and TCWC data as well as other sources of data, e.g. JTWC, and (ii) IBTrACS_WMO, which only contains TC data collected from WMO-sanctioned forecast agencies, e.g. RSMCs and TCWCs, and is a subset of the more comprehensive database. See https://www.ncdc.noaa.gov/ibtracs/index.php? name=ibtracs-data-access for more detail on the differences between IBTrACS_WMO and IBTrACS_ALL. This analysis utilises the IBTrACS_ALL data set. The use of IBTrACS_ALL database in TC studies is widespread (e.g. Ramsay et al., 2011; Liu and Chan, 2012).

The Southwest Pacific Enhanced Archive of Tropical Cyclones (SPEArTC) is the most recent reanalysis of available BTs for the SWP (Diamond et al., 2012). Building upon the
IBTrACS database, SPEArTC incorporates a number of new sources of older scanned data coupled with a meticulous reanalysis of all of these sources from 1840 to the present. However, given the lack of observational data in the early part of the record, the developers note that some TC seasons are missing between 1840 and 1905. In the creation of SPEArTC, some unique quality control and duplicate track detection processes were established, such as the Graphical Interpretation of Tracks (GrIT) method (Diamond et al., 2012), which applied objective and subjective guidelines to investigate duplicate events and to highlight possible errors. The data set is utilised in the following studies: Diamond et al. (2013) and Diamond and Renwick (2015a, b).

\subsection{Tropical cyclone data used in this study}

Three quality-controlled TC BT products discussed in Sect. 2.1. were obtained:

- JTWC (data set updated 8 July 2014: http: //www.usno.navy.mil/NOOC/nmfc-ph/RSS/jtwc/ best_tracks/index.html (Chu et al., 2002)

- IBTrACS (v03r06: http://www.ncdc.noaa.gov/ibtracs/ index.php?name=ibtracs-data) (Knapp et al., 2010)

- SPEArTC (data set updated 28 January 2014: http: //apdrc.soest.hawaii.edu/projects/speartc/) (Diamond et al., 2012).

As discussed in Sect. 1, Holland (1981) used the Lourensz TC database (Lourensz, 1977, 1981) to assess the quality of 
the Australian TC record. As such, the Lourensz TC database is used in this analysis and compared with the more contemporary quality-controlled SPEArTC database.

The SWP TC season is from 1 November to 30 April of the following year (Terry, 2007). As the TC season straddles the Gregorian calendar year, events that occur during November and December are considered part of the following year's TC season (see Dowdy, 2014). For example, TCs that occur in November and December 2010 are considered part of the 2011 TC season. The IBTrACS database was modified to the same reporting system to ensure homogeneity across the three databases.

The lack of a unified method in collecting and recording TC data has resulted in numerous data formats (Schreck et al., 2014). During initial inspection of the IBTrACS database, these inconsistencies were identified, typically as duplications of parts of a TC track. As such, only "main" TC tracks have been used in this analysis and the other categories, "merge", "split" and "other", were not included.

\subsection{Reanalysis data}

This study utilises 20th Century Reanalysis Version 2 (20CRv2) from the National Oceanic and Atmospheric Administration Earth System Research Laboratory (Compo et al., 2011). The 20CRv2 has four synoptic observations per day and is ideal for this environmental reanalysis. To investigate whether environmental conditions were suitable for TC genesis on selected dates, five geophysical parameters are investigated: (i) $700 \mathrm{hPa}$ vorticity (VORT) or the vertical component of the vorticity vector is calculated by Eq. (1), whereby $u / v$ refers to zonal/meridional winds at $700 \mathrm{hPa}$ and $x / y$ refer to coordinate axes (McBride and Zehr 1981):

$\zeta=\partial v / \partial x-\partial u / \partial y$

(ii) $700 \mathrm{hPa} u / v$ winds; (iii) Environmental Wind Shear (EVWS) is calculated by the difference in $200 \mathrm{hPa}$ and $850 \mathrm{hPa} u / v$ winds (see Eq. 2) (Gray, 1968):

$\mathrm{EVWS}=\sqrt{(u 200-u 850)^{2}+(v 200-v 850)^{2}} ;$

(iv) Vertical Shear of Zonal Wind (VSZW) is calculated by the difference in zonal winds $(u)$ between $200 \mathrm{hPa}$ and $850 \mathrm{hPa}$ (see Eq. 3) (Nolan and McGauley, 2012):

$\mathrm{VSZW}=u 200-u 850$;

and (v) $700 \mathrm{hPa}$ geopotential height (GPH).

This analysis calculated both anomalous (VORT, VSZW, GPH) and absolute conditions ( $700 \mathrm{hPa}$ winds, EVWS) to determine whether conditions were suitable for TC genesis. Anomaly values represent deviations from the mean climatological state (1981-2010). The conditions most suited to TC genesis are discussed further in Sect. 3.2.

To validate the choice of environmental parameters used in this analysis, the above reanalysis fields were assessed during known TCs from the Australian landfalling TC database
(Callaghan and Power, 2011). Five TCs were randomly selected from the 18 TCs that made landfall within the study domain (between 1945 and 2011; see Table 3). Using the SPEArTC database, landfalling TCs were traced back to their point of TC genesis and the environmental conditions were assessed on the date of genesis. Plots of the environmental conditions have been included as Supplement (Figs. S1S5). A checklist of conditions for each event (Table 3) indicates that anomalously negative $700 \mathrm{hPa}$ VORT, absolute cyclonic $700 \mathrm{hPa}$ winds and absolute EVWS $\left(<=10 \mathrm{~m} \mathrm{~s}^{-1}\right)$ were present in the immediate vicinity of TC genesis for four of five TC events (see Sect. 3.2 for more information). Anomalously negative $700 \mathrm{hPa} \mathrm{GPH}$ and anomalously westerly VSZW occurred for three out of five events, confirming that our choice of parameters provides a reasonable indication of conditions conducive to TC development. It should be noted that this method is not used as a TC forecasting technique; rather to verify the choice of reanalysis fields for this analysis.

\section{Methodology}

\subsection{Spatio-temporal comparison of tropical cyclone databases}

In our analysis, annual (July-June) TC counts are considered along with two subsets of the TC season: the first half of the TC season, November to January (NDJ), and the second half of the TC season, February to April (FMA). Time series analysis compares annual and seasonal TC counts for JTWC, IBTrACS and SPEArTC. The average number of TCs per year and per season was also compared between databases. For the purposes of this analysis, the point of TC genesis is defined as the first point of each unique TC track for each TC database.

Difference density plots are used to assess the spatial variability between JTWC, IBTrACS and SPEArTC. The frequency of annual TC events in $2.5^{\circ} \times 2.5^{\circ}$ grid cells was calculated for each of the three databases and subtracted from one another. This resulted in three pairings: JTWCIBTrACS, JTWC-SPEArTC and IBTrACS-SPEArTC. Positive/negative values indicate more/fewer TCs in the respective grid cells.

\subsection{Cross comparison of tropical cyclone best-track databases and environmental reanalysis}

By comparing TC counts between JTWC, SPEArTC and IBTrACS, we identified two TC seasons with the largest deviation in annual TC counts between JTWC, IBTrACS and SPEArTC, 1968 and 1981. TC events were subsequently categorised into one of three categories: (i) exact matches (TCs that match in all three BT databases), (ii) partial matches (conflicting date, latitude and longitude) and (iii) unique events (events that do not feature in any of the 


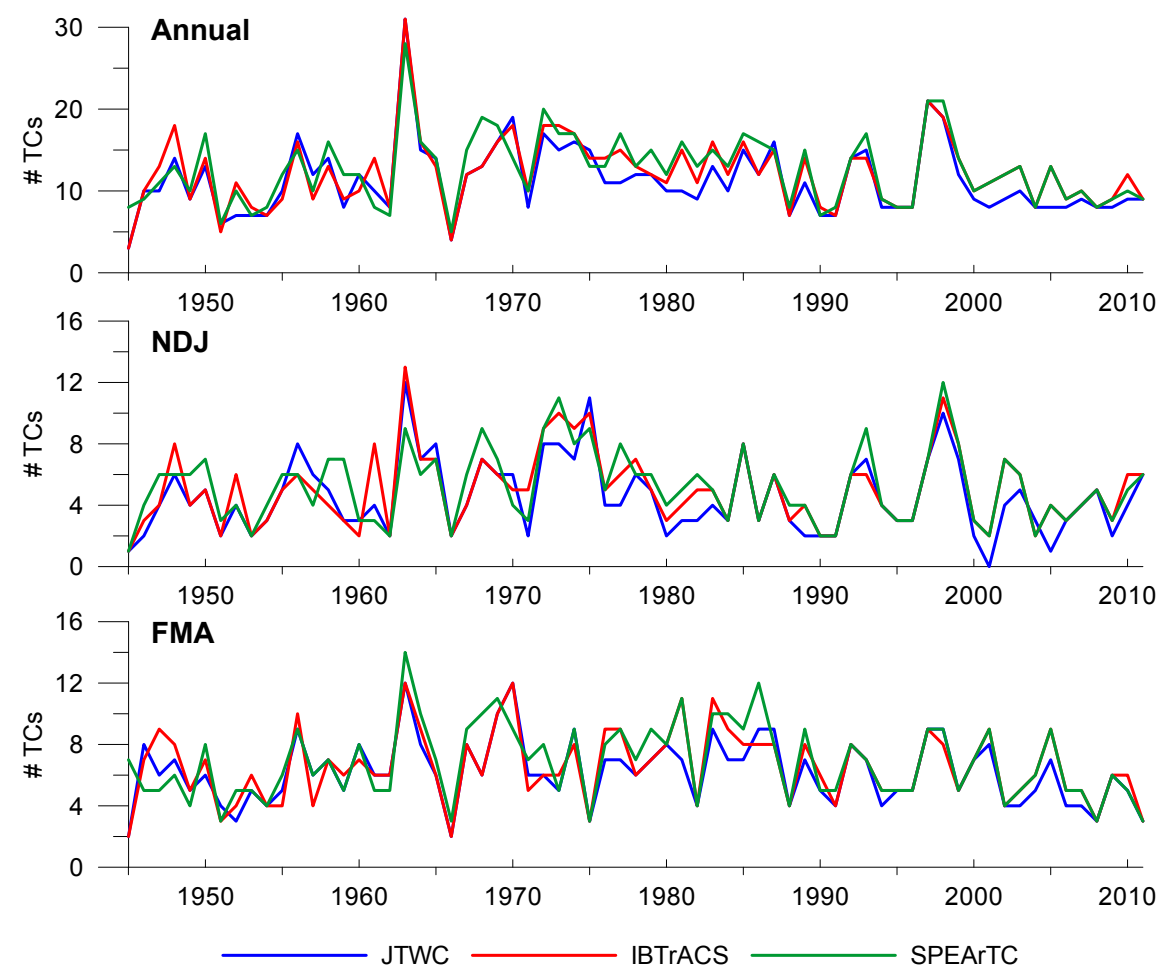

Figure 2. Time series of annual and seasonal TC counts (1945-2011) for JTWC, IBTrACS and SPEArTC databases.

other databases). To identify whether the TCs classified as unique events were legitimate TCs, we use 20CR data (see Sect. 2.3) to establish if environmental conditions for the selected TC seasons were suitable for TC genesis. Anomaly values of key environmental conditions required for TC genesis are assessed. Using a climatological baseline of 19812010, anomaly values are compared with the location of TC genesis to determine whether environmental conditions are suited or not to TC genesis. Anomalous conditions suited to TC genesis include: negative $700 \mathrm{hPa}$ VORT (Gray, 1968; McBride and Zehr, 1981), negative (westerly) zonal shear (TC genesis can also occur in a region of easterly zonal shear; Nolan and McGauley, 2012) and negative $700 \mathrm{hPa}$ GPH anomalies (Goebbert and Leslie, 2010; Diamond and Renwick, 2015a). Upon assessing the geophysical parameters, we classified the environmental conditions as suitable or less suitable for TC genesis.

Absolute values of cyclonic $700 \mathrm{hPa}$ winds (HendersonSellers et al., 1998) and wind shear are included in this analysis. Absolute EVWS values between 2 and $4 \mathrm{~m} \mathrm{~s}^{-1}$ are most favourable for TC genesis, while EVWS values exceeding $10 \mathrm{~m} \mathrm{~s}^{-1}$ do not favour intensification of a TC system (Paterson et al., 2005). As such, if TC genesis occurs in a region where shear exceeds $10 \mathrm{~m} \mathrm{~s}^{-1}$, conditions will be deemed less favourable (but still possible) for TC genesis. For the purposes of this study, we are investigating whether environmental conditions were suitable for TC genesis. We are not suggesting that $\mathrm{TC}$ genesis occurred and that particular event intensified into a TC. The authors acknowledge the caveats of using reanalysis data as a method to verify historical TCs (Nicholls et al., 1998)

\subsection{Assessing the impact of changing observational technologies on the quality of tropical cyclone databases}

As an update and extension to previous work (Holland, 1981), herein the work of Holland, we investigate the potential impact of changing observational technologies on the quality of JTWC, IBTrACS and SPEArTC. We use the introduction of two "significant" observational technologies, the satellite era (1969) and routine geostationary satellites (1982) as breakpoints in the time series (Holland, 1981; Nicholls et al., 1998). As such, our TC time series consists of three time periods: 1945-1969 (pre-satellite era), 19702011 (post-satellite era) and 1982-2011 (post-geostationary satellite era).

Assessing the statistical significance of differences in TC counts between time periods was addressed in two ways: (i) a non-parametric Mann-Whitney U test and (ii) a parametric generalised linear mixed model (GLMM). A MannWhitney U test (Mann and Whitney, 1947) is used to compare the median values of the pre-satellite, post-satellite and post-geostationary satellite TC counts. Furthermore, a parametric generalised linear mixed model (GLMM) is applied to compare mean TC counts between each of the time periods 


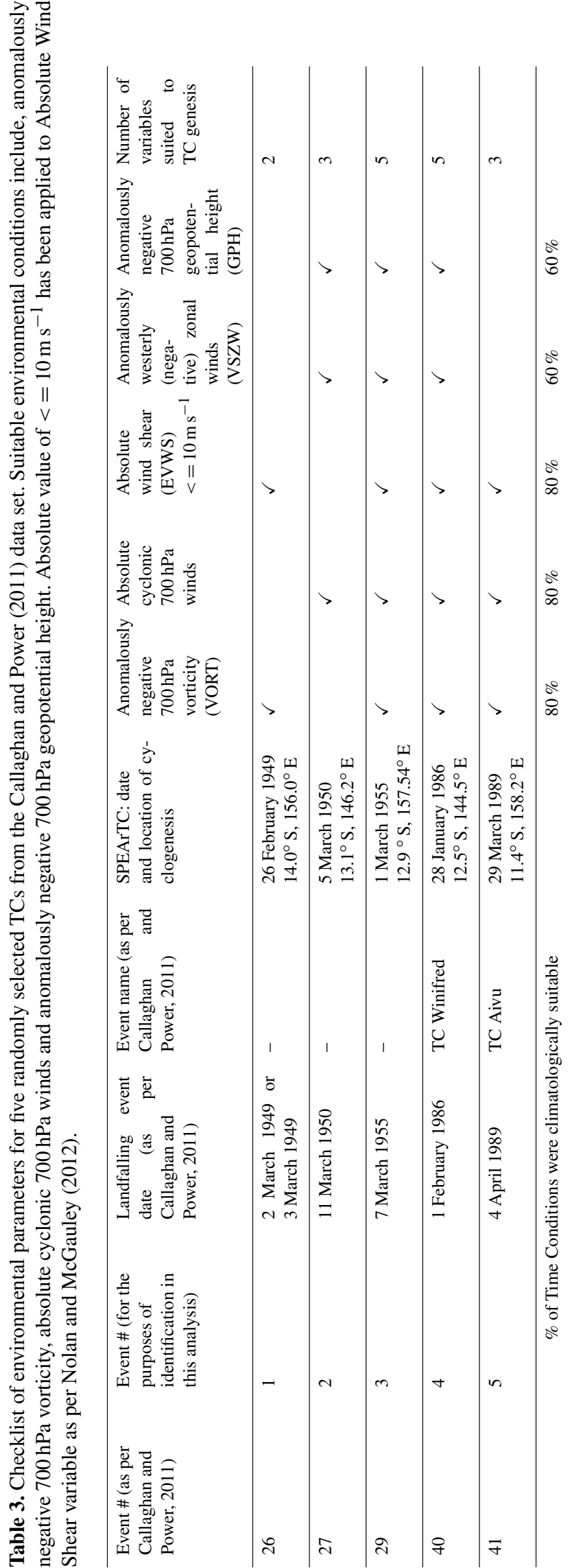

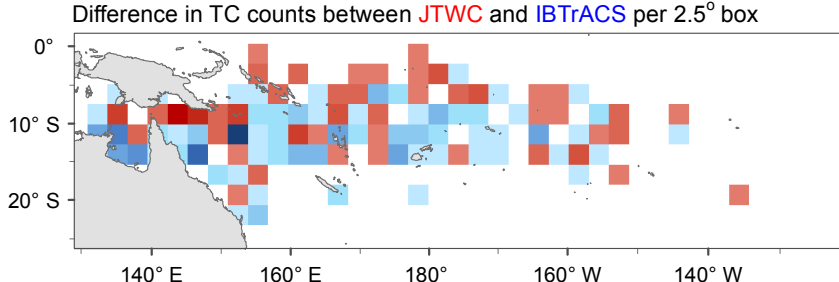
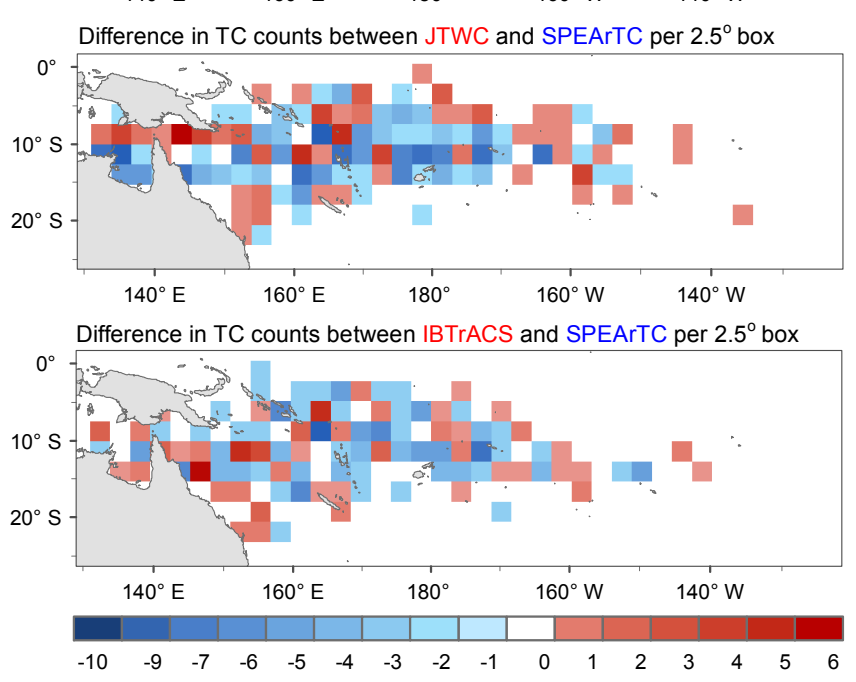

Figure 3. Difference (total annual TC counts) between various pairings of TC databases from 1945 to 2011. Red (blue) values correspond to more TC counts in TC database named in red (blue).

and derive a statistical significance of the values (McCulloch and Neuhaus, 2001). The Poisson distribution has been used to model variability, as this is a suitable choice for counted data (Sabbatelli and Mann, 2007). A random effect was used to account for possible overdispersion due to differences in TC counts between years, for example, large outlier TC seasons such as 1962/1963. The significance of differences in TC counts was assessed from the mixed-model main-effect term of the two versions of the time period: (i) 1945-1969 vs. 1970-2011 and (ii) $1945-1981$ vs. 1982-2011. As we are using these statistical tests to investigate whether changing observational technologies has a substantial influence on TC counts, a $p$ value $<0.05$ would indicate a statistically significant value.

In addition to assessing temporal variability caused by changing observational technologies, we also investigate the spatial variability of TC activity influenced by the introduction of each technology. This study makes use of mean genesis locations (Chand and Walsh, 2010; Wu et al., 2015), calculated by averaging the latitude $(x)$ and longitude $(y)$ of a collection of TC events. The mean centre of cyclogenesis (MCC) technique provides an insight into how the introduction of various observational technologies has impacted TC genesis. The vast longitudinal and latitudinal expanse of the study area is acknowledged; however this technique provides 
Table 4. Average annual and seasonal TC frequency for JTWC, IBTrACS and SPEArTC database from 1945 to 2011.

\begin{tabular}{|c|c|c|c|c|c|c|c|}
\hline & & \multicolumn{2}{|c|}{ JTWC } & \multicolumn{2}{|c|}{ IBTrACS } & \multicolumn{2}{|c|}{ SPEArTC } \\
\hline & & $\begin{array}{r}\text { Total number } \\
\text { of TCs }\end{array}$ & $\begin{array}{r}\text { Average number } \\
\text { of TCs year }\end{array}$ & $\begin{array}{r}\text { Total number } \\
\text { of TCs }\end{array}$ & $\begin{array}{r}\text { Average number } \\
\text { of TCs year }^{-1}\end{array}$ & $\begin{array}{r}\text { Total number } \\
\text { of TCs }\end{array}$ & $\begin{array}{r}\text { Average number } \\
\text { of TCs year }\end{array}$ \\
\hline \multirow{3}{*}{$1945-2011$} & Annual & 753 & 11.2 & 815 & 12.2 & 844 & 12.6 \\
\hline & NDJ & 303 & 4.5 & 337 & 5.0 & 350 & 5.2 \\
\hline & FMA & 414 & 6.2 & 438 & 6.5 & 456 & 6.8 \\
\hline
\end{tabular}

Table 5. Checklist of variables representing the environmental conditions conducive to tropical cyclogenesis for each cyclone ID \#. See plots summarising geophysical parameters (Figs. 5-7) for events in bold. Suitable anomaly/absolute conditions are listed in the respective headers (anomalies calculated using 1981-2010 climatology from 20CR, Compo et al., 2011). Ticks indicate whether these conditions were present in the vicinity of TC genesis. $\mathrm{x}$ indicates conditions were not present in the vicinity of TC genesis and were therefore less favourable.

\begin{tabular}{|c|c|c|c|c|c|c|c|c|}
\hline $\begin{array}{l}\text { Cyclone } \\
\text { TC \# }\end{array}$ & Date & Latitude & Longitude & $\begin{array}{c}\text { Anomalously } \\
\text { negative } \\
700 \mathrm{hPa} \text { vorticity (VORT) }\end{array}$ & $\begin{array}{c}\text { Absolute } \\
\text { cyclonic } \\
700 \mathrm{hPa} \text { winds }\end{array}$ & $\begin{array}{l}\text { Absolute wind shear } \\
\qquad \begin{array}{l}\text { (EVWS) } \\
<=10 \mathrm{~m} \mathrm{~s}^{-1}\end{array}\end{array}$ & $\begin{array}{l}\text { Anomalously westerly } \\
\text { (negative) } \\
\text { zonal winds (VSZW) }\end{array}$ & $\begin{array}{c}\text { Anomalously } \\
\text { negative } \\
700 \mathrm{hPa} \mathrm{GPH}\end{array}$ \\
\hline 1 & 1 Jan 1968 & -15.4 & 162.99 & $\mathrm{x}$ & $\mathrm{x}$ & $\checkmark$ & $\mathrm{x}$ & $\mathrm{x}$ \\
\hline 2 & 23 Jan 1968 & -27.43 & 173.18 & $\checkmark$ & $\checkmark$ & $\checkmark$ & $\checkmark$ & $\checkmark$ \\
\hline 3 & 8 Feb 1968 & -16.06 & 188.15 & $\checkmark$ & $\checkmark$ & $\checkmark$ & $\mathrm{x}$ & $\checkmark$ \\
\hline 4 & 11 Feb 1968 & -8.83 & 161.23 & $\checkmark$ & $\checkmark$ & $\checkmark$ & $\checkmark$ & $\checkmark$ \\
\hline 5 & 21 Feb 1968 & -23.78 & 171.86 & $\checkmark$ & $\checkmark$ & $\mathrm{x}$ & $\checkmark$ & $\checkmark$ \\
\hline 6 & 20 Mar 1968 & -20.3 & 177.8 & $\checkmark$ & $\checkmark$ & $\mathrm{x}$ & $\checkmark$ & $\checkmark$ \\
\hline 7 & 1 Dec 1980 & -12.68 & -174.01 & $\checkmark$ & $\checkmark$ & $\checkmark$ & $\mathrm{x}$ & $\mathrm{x}$ \\
\hline
\end{tabular}

an effective comparison of the spatio-temporal modulation of TC activity.

\section{Results and discussion}

\subsection{Spatio-temporal comparison of JTWC, IBTrACS and SPEArTC tropical cyclone databases}

Comparing the annual and seasonal TC counts (Table 4, Fig. 2) highlights variability between the three BT products. The most conservative (i.e. lowest number of TCs listed in the database) is JTWC, which lists a total of $753 \mathrm{TC}$ events between 1945 and 2011. In contrast, SPEArTC contains 844 events, a difference of 91 TCs (approximately $12 \%$ more than JTWC). This same pattern is evident seasonally, e.g. NDJ with 47 more TCs (a difference of 15.5\%) in SPEArTC compared with JTWC. A number of years show a higher degree of temporal variability between databases, which is investigated further in Sect. 4.2.

Difference density plots were created to assess spatial variability between the three TC databases (method detailed in Sect. 3.1). In Fig. 3, the first two pairings for the difference density plot use JTWC as a base, therefore positive (negative) values indicate more (fewer) events in JTWC (IBTrACS/SPEArTC). The last pairing, IBTrACS-SPEArTC, indicates that positive (negative) values indicate more (fewer) events in IBTrACS (SPEArTC). The JTWC-SPEArTC pairing highlights the greatest spatio-temporal difference in TC counts between our paired TC databases. In total, $42.6 \%$ of the area recorded more SPEArTC events than JTWC. TC counts for the IBTrACS-SPEArTC pairing are the most consistent with $40.4 \%$ of the total area containing the same number of TCs. The greatest inconsistency occurs around the Gulf of Carpentaria and the Coral Sea.

The results presented thus far confirm that spatial and temporal inconsistencies exist between JTWC, IBTrACS and SPEArTC. Therefore, conclusions drawn from TC-related analyses may be influenced by the choice of BT database depending on the application.

\subsection{Cross comparison of tropical cyclone best-track products}

An analysis of JTWC, IBTrACS and SPEArTC revealed that the years with the largest discrepancy in TC frequency were the 1968 and 1981 TC season. For these two TC seasons, each TC event was categorised into one of three distinct TC categories: (i) exact matches, where temporal/spatial data (date, latitude and longitude) are identical in each TC database; (ii) matched TCs with inconsistent temporal/spatial data and (iii) unique events (an event that is only recorded in one TC database; Fig. 4). Both the pre-satellite (1968) and post-satellite (1981) era are represented in this analysis, the significance of which is explored in Sect. 5.

For the 1968 TC season, seven exact TC matches were noted. A further six matching events had inconsistent spatiotemporal data, but were identified as the same TC event (see Fig. 4a) and six unique TCs were identified in SPEArTC (Fig. 4b). The literature offers a number of explanations to 

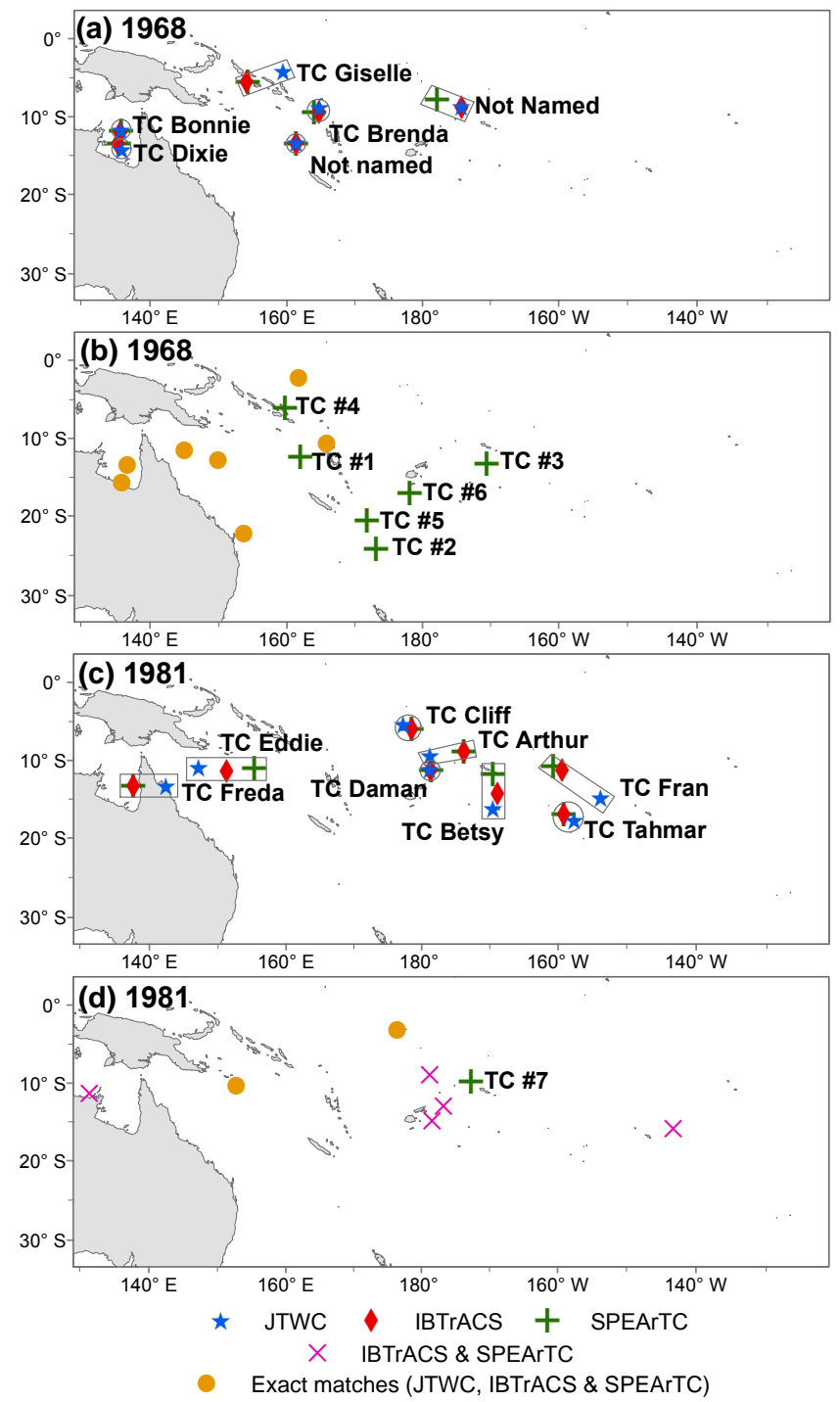

Figure 4. Cross comparison of JTWC, IBTrACS and SPEArTC TC events for two seasons: 1968 (a, b) and 1981 (c, d). Panels (a) and (c) plot TCs that partially match across each database (conflicting date, latitude and longitude). Panels (b) and (d) plot TCs that are exact matches across all three BT products and unique TC events that do not feature in any of the other databases.

account for conflicting information (date/location) including (i) difficulty and subjectivity in defining a BT (Holland, 1981), (ii) an acceptable margin of error of up to $110 \mathrm{~km}$ when collating BT data (Chu et al., 2002) and (iii) inconsistencies in operational procedures (Knapp and Kruk, 2010; Diamond et al., 2012). TC Gisele is one such event which was recorded in all three BT products; however, the point of TC genesis for TC Gisele as listed in IBTrACS and SPEArTC is located approximately $498 \mathrm{~km} \mathrm{SW}$ from JTWC.

For the 1981 TC season, two exact matches were noted, while eight TC events are classified as matching with inconsistent temporal/spatial data (Fig. 4c). The spatial variability between each matching TC event is considerably more than the $1968 \mathrm{TC}$ season, with spatial differences of up to $781 \mathrm{~km}$ between BT product for TC Fran, $756 \mathrm{~km}$ for TC Eddie and $480 \mathrm{~km}$ for TC Betsy. There is one unique TC in 1981 identified in the SPEArTC database (Fig. 4d). The fewer unique events in the 1981 TC season compared to the 1968 TC season may be indicative of the improved observational technologies in the post satellite era. Section 4.3 further explores the pre-satellite, post-satellite and post-geostationary satellite era and provides a spatio-temporal comparison of each $\mathrm{BT}$ product.

To assess the environmental conditions associated with the unique TC events identified in SPEArTC, we perform an analysis based on four geophysical parameters required for TC genesis (see validation of the use of these variables in Sect. 3.2). The purpose of this technique is twofold: (i) to ensure that conditions are suited to TC genesis and (ii) to verify the inclusion of these events within the SPEArTC database. Table 5 summarises a checklist of the parameters required for TC genesis for each unique TC event. The cyclone ID no. is used as an identifier which corresponds to Fig. $4 \mathrm{~b}$ and d. An inspection of each geophysical variable confirms (for TC\# 27) that many of the environmental conditions were suitable for TC genesis (for TC\# 2-7), particularly for $700 \mathrm{hPa}$ Vorticity, $700 \mathrm{hPa}$ Winds, westerly VSZW and $700 \mathrm{hPa}$ GPH. To highlight how this conclusion was drawn, Figs. 5-7 plot the anomaly values for the selected geophysical parameters for two selected events: TC \#3 (1968) and TC \#7 (1981).

The vorticity and wind plots (Fig. 5) demonstrate that conditions were suitable for TC genesis during the two unique events, given that anomalously negative vorticity and absolute cyclonic-like wind-flow patterns comprise all conditions suitable for TC genesis. In fact, areas of substantial negative vorticity are evident for six of the seven events analysed in this study. Absolute EVWS $<10 \mathrm{~m} \mathrm{~s}^{-1}$ is generally more favourable for TC genesis (Nolan and McGauley, 2012), which occurred in the region of TC genesis for TC \#3 and TC \#7 (Fig. 6a-b) and for a total of five of the seven TC events analysed. While TCs \#3 and \#7 do not occur in a region of westerly VSZW (Fig. 6c-d), four of the seven events do (Table 5). As outlined by Nolan and McGauley (2012), TC genesis can also occur in areas of positive (easterly) shear. Five of the seven TC events analysed (Table 5) occur in a region of anomalously negative GPH, most suited for TC genesis. TC genesis in Fig. 7a, occurs in a region of anomalously negative GPH, while TC \#7 (Fig. 7b) occurs in a region of neutral GPH.

Although it is difficult to determine if the conditions observed during the TC event matured into a TC and satisfy the minimum wind speed requirements to be defined as a $\mathrm{TC}$, the analysis of environmental parameters confirms that conditions were favourable for TC genesis for each of the seven events analysed. Therefore, given that the SPEArTC database is likely to be the most complete for the SWP re- 
(a) Vorticity - TC\# 3, 1968

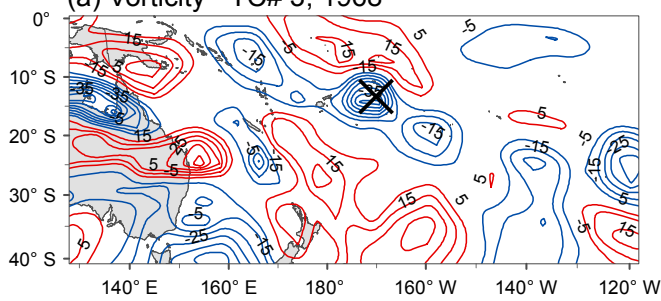

(b) Vorticity - TC\# 7, 1981

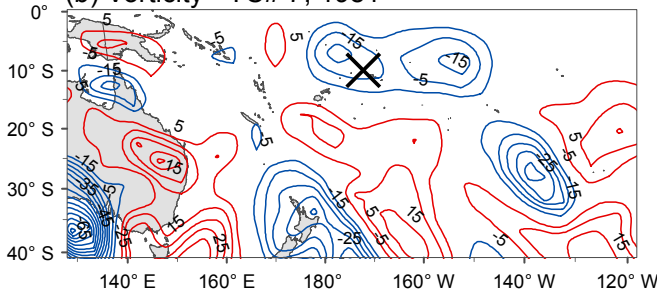

(c) Winds - TC\# 3, 1968

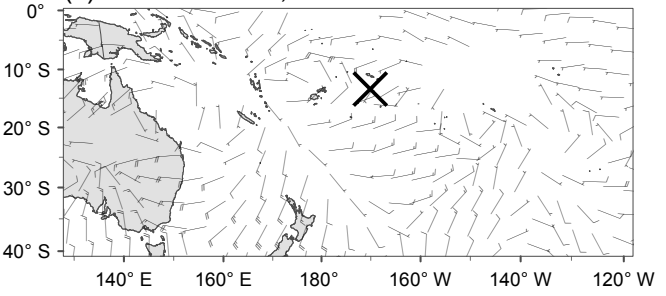

(d) Winds - TC\# 7, 1981

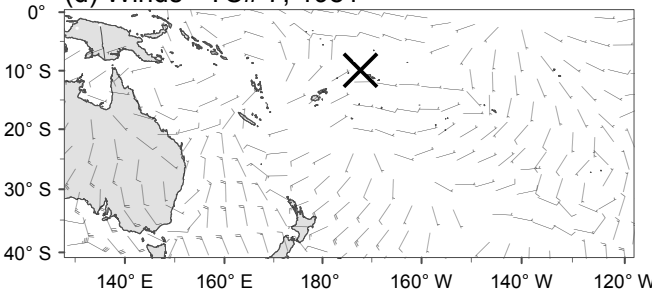

Figure 5. Vorticity plots for (c) TC \#3, 1968 and (d) TC \#7, 1981, and wind plots for (a) TC \#3, 1968 and (b) TC \#7, 1981. Anomalies of vorticity $\left(5 \mathrm{~s}^{-1} \times 10^{-6}\right.$ contours): blue - negative, red - positive; zero contour omitted; $700 \mathrm{hPa} \mathrm{U}$ - and V-winds ( $5 \mathrm{kt}$ contour barbs) based on 1981-2010 climatology from 20th Century Reanalysis (Compo et al., 2011). Black marker indicates mean centre of cyclogenesis (MCC).

(a) EVWS - TC\# 3, 1968

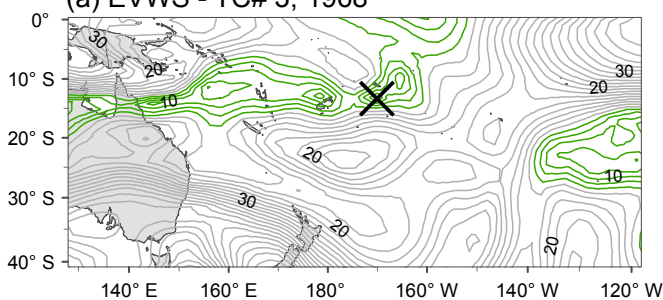

(b) EVWS - TC\# 7, 1981

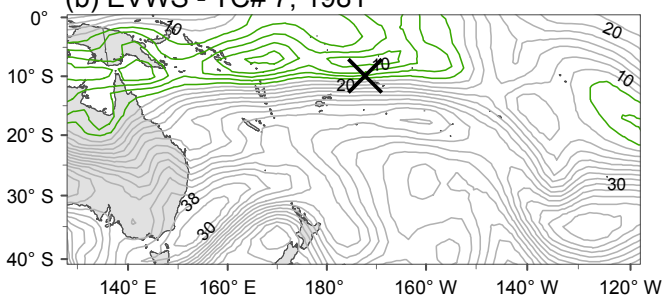

(c) VSZW - TC\# 3, 1968

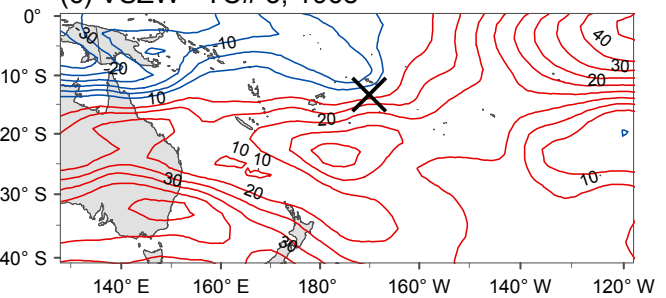

(d) VSZW - TC\# 7, 1981

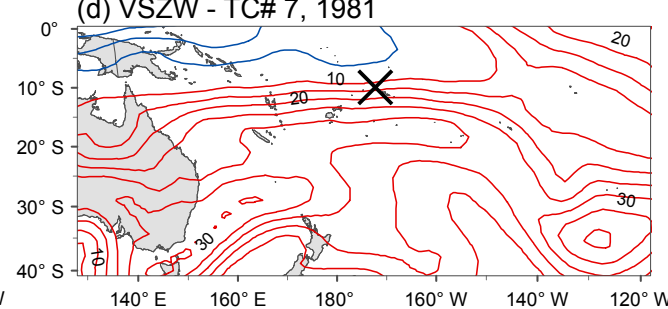

Figure 6. Environmental vertical wind shear (EVWS) plots for (a) TC \#3, 1968 and (b) TC \#7, 1981, and vertical shear of zonal wind (VSZW) plots for (c) TC \#3, 1968 and (d) TC \#7, 1981. Absolute EVWS values ( $2 \mathrm{~m} \mathrm{~s}^{-1}$ contours): green - wind shear $<=10 \mathrm{~m} \mathrm{~s}{ }^{-1}$, grey - wind shear $>10 \mathrm{~m} \mathrm{~s}^{-1}$. Anomalies of VSZW (10 $\mathrm{m} \mathrm{s}^{-1}$ contours): blue - negative, red - positive; zero contour omitted. Calculated using 20th Century Reanalysis (Compo et al., 2011) and VSZW calculated based on 1981-2010 climatology. Black marker indicates mean centre of cyclogenesis (MCC).

gion, we focus on this database for our temporal analysis in the following section.

\subsection{Assessing the impact of changing observational technologies on the quality of tropical cyclone databases}

Given the importance of a reliable, homogenous data set, many studies have opted to use only post-satellite TC data based on previous work (Holland, 1981). However, with the development of more contemporary TC databases, this assumption needs to be reviewed. To achieve this, an intercomparison of annual TC counts was carried out between the same Lourensz TC database (Lourensz, 1977) used in the findings of Holland and the SPEArTC database. To lengthen the Lourensz TC database (Lourensz, 1977) to 1980, we utilised data from an extended Lourensz TC data set (Lourensz, 1981). In this comparative study only TCs that occurred between $135-165^{\circ} \mathrm{E}, 5-32^{\circ} \mathrm{S}$ (i.e. a subset of the wider SWP study region) during 1945-1980 were considered in this analysis (the common spatial and temporal extents 
Table 6. Annual and seasonal mean SPEArTC TC counts according to pre-satellite (1945-1969), post-satellite (1970-2011) and postgeostationary satellite (1982-2011) era.

\begin{tabular}{llr}
\hline & Season & $\begin{array}{r}\text { Mean SPEArTC } \\
\text { Counts }\end{array}$ \\
\hline \multirow{3}{*}{$1945-1969$} & Annual & 12.2 \\
& NDJ & 5.1 \\
& FMA & 6.7 \\
\hline \multirow{4}{*}{$1970-2011$} & Annual & 12.8 \\
& NDJ & 5.3 \\
& FMA & 6.9 \\
\hline \multirow{3}{*}{$1982-2011$} & Annual & 12.0 \\
& NDJ & 4.8 \\
& FMA & 6.5 \\
\hline
\end{tabular}

of all databases). Figure 8a shows that, although the same spatial and temporal boundaries have been applied for this comparison, annual TC counts for the Lourensz TC data set (5.1 TCs per year) are considerably lower than the SPEArTC database (7.4 TCs per year). This result is somewhat expected given the improved technologies available to identify historical TCs and construct the contemporary TC databases. Interestingly, the magnitude of the upward trend in eastern region TCs $\left(135-165^{\circ} \mathrm{E}, 5-32^{\circ} \mathrm{S}\right)$ for the Lourensz TC database (Fig. 8a) is not as noteworthy as for the wider Australian region $\left(105-165^{\circ}\right.$ E, $5-32^{\circ} \mathrm{S}$; Fig. $\left.8 \mathrm{~b}\right)$, originally investigated by Holland (although both trend lines are statistically significant at $a=0.01$ based on a Mann-Kendall test of linear trend). This suggests that the western and northern region (west of $135^{\circ} \mathrm{E}$ ) of the Lourensz database was the dominant driver of the observed increasing trend in TC counts in the original study. Further, when SPEArTC TC counts for the same region (from 1945) are overlaid in Fig. 8a, although a slight increase is observed with time, the increase is not as substantial as in the original Lourensz TC database and importantly, the trend is not statistically significant $(a=0.05)$ when the data are extended to 2011 (based on a MannKendall test). This not only suggests that the original TC database has been superseded by more contemporary TC databases; more importantly, any conclusions on pre-satellite era data require re-examination using these contemporary TC databases.

There is no doubt that the introduction of new observational technologies has improved our ability to detect, monitor and disseminate more accurate information on TCs. However, a comparison of pre- and post-satellite era SPEArTC TC counts over the full SWP study region $\left(0-35^{\circ} \mathrm{S}, 135^{\circ} \mathrm{E}-\right.$ $120^{\circ} \mathrm{W}$ ) suggests that pre-satellite era data are not as erroneous and missing as many TCs as previous studies suggest (based on temporal, statistical and spatial analysis; Table 6). A comparison of average annual TC counts highlighted a small difference between the pre-satellite era and (a) GPH - TC\# 3, 1968

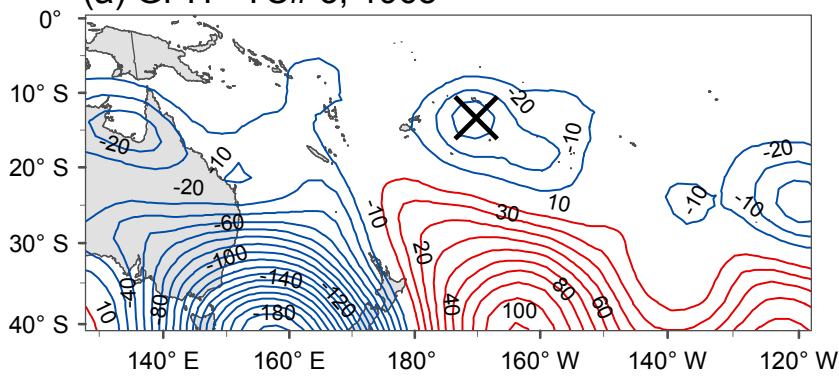

(b) GPH - TC\# 7, 1981

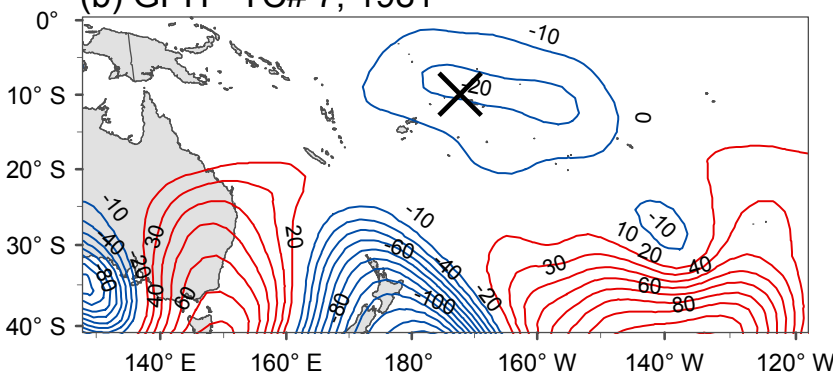

Figure 7. Geopotential Height (GPH) for (a) TC \#3, 1968 and (b) TC\#7, 1981. Anomalies of GPH (10 gpm contours): blue - negative, red - positive; zero contour omitted. Based on 1981-2010 climatology from 20th Century Reanalysis (Compo et al., 2011). Black marker indicates mean centre of cyclogenesis (MCC).

post-satellite eras at 12.2 and $12.8 \mathrm{TCs}$ per year respectively. Had the introduction of the satellite era had a significant influence on the number of TCs (whereby $30-50 \%$ of TC observations were missing from the Lourensz TC database; Holland, 1981), then it would be expected that the average number of TCs in the post-satellite era would be significantly elevated compared to the pre-satellite era. Further, cross-referencing pre-satellite era SPEArTC events with known TCs from the Australian landfalling TC database by Callaghan and Power (2011), highlights that all TCs that made landfall between Ballina and Cairns are accounted for in the SPEArTC database (Table 7).

To determine (statistically) if changing observational technologies had a significant influence on TC counts (and therefore the temporal quality of the database), a Mann-Whitney $\mathrm{U}$ test and generalised linear mixed model (GLMM) were applied to the SPEArTC database. TC counts for two scenarios were compared: 1945-1969 (pre-satellite era) with 19702011 (post-satellite) and 1945-1981 with 1982-2011 (postgeostationary satellite era). The null hypothesis adopted was that there is no difference between the median (MannWhitney U) and mean (GLMM) in SWP TC counts before and after the change in technology. Table 8 shows for all time periods assessed, each test for SPEArTC returned $p$ values $>0.05$, suggesting there is no statistical evidence against the null hypothesis. These results confirm that there is no statistical evidence to suggest that there is a significant change 
Table 7. List of landfalling TCs used in the Callaghan and Power (2011) database from 1945. Events have been cross-referenced with SPEArTC databases with the date and location of TC genesis listed.

\begin{tabular}{|c|c|c|c|}
\hline $\begin{array}{r}\text { Event \# } \\
\text { (as per Callaghan } \\
\text { and Power, 2011) }\end{array}$ & $\begin{array}{l}\text { Landfalling event } \\
\text { date (as per Callaghan } \\
\text { and Power, 2011) }\end{array}$ & $\begin{array}{l}\text { Event name) } \\
\text { (as per Callaghan } \\
\text { and Power, 2011) }\end{array}$ & $\begin{array}{l}\text { SPEArTC: date and } \\
\text { location of } \\
\text { TC genesis }\end{array}$ \\
\hline 26 & 2/3 March 1949 & - & $\begin{array}{l}26 \text { February } 1949 \\
14.0^{\circ} \mathrm{S}, 156.0^{\circ} \mathrm{E}\end{array}$ \\
\hline 27 & 11 March 1950 & - & $\begin{array}{l}5 \text { March } 1950 \\
13.1^{\circ} \mathrm{S}, 146.2^{\circ} \mathrm{E}\end{array}$ \\
\hline 28 & 20 February 1954 & - & $\begin{array}{l}12 \text { February } 1954 \\
10.7^{\circ} \mathrm{S}, 177.7^{\circ} \mathrm{E}\end{array}$ \\
\hline 29 & 7 March 1955 & - & $\begin{array}{l}1 \mathrm{March} 1955 \\
12.9^{\circ} \mathrm{S}, 157.54^{\circ} \mathrm{E}\end{array}$ \\
\hline 30 & 6 March 1956 & TC Agnes & $\begin{array}{l}24 \text { February } 1956 \\
17.0^{\circ} \mathrm{S}, 175.0^{\circ} \mathrm{E}\end{array}$ \\
\hline 31 & 1 April 1958 & - & $\begin{array}{l}31 \text { March } 1958 \\
17.4^{\circ} \mathrm{S}, 150.8^{\circ} \mathrm{E}\end{array}$ \\
\hline 32 & 16 February 1959 & TC Connie & $\begin{array}{l}11 \text { February } 1959 \\
15.6^{\circ} \mathrm{S}, 152.56^{\circ} \mathrm{E}\end{array}$ \\
\hline 33 & 28/30 January 1967 & TC Dinah & $\begin{array}{l}\text { 22 January } 1967 \\
11.9^{\circ} \mathrm{S}, 165.1^{\circ} \mathrm{E}\end{array}$ \\
\hline
\end{tabular}

Table 8. $p$ values of Mann-Whitney U test and generalised linear mixed model (GLMM) on SPEArTC counts for pre-satellite, post-satellite and post-geostationary satellite eras (annual and seasonal).

\begin{tabular}{lcc|cc}
\hline & \multicolumn{2}{c|}{ Mann-Whitney U test } & Generalised linear mixed model (GLMM) \\
\cline { 2 - 5 } & 1945-1969 vs. 1970-2011 & 1945-1981 vs. 1982-2011 & 1945-1969 vs. 1970-2011 & 1945-1981 vs. 1982-2011 \\
\hline Annual & 0.34 & 0.34 & 0.62 & 0.23 \\
NDJ & 0.97 & 0.16 & 0.38 & 0.12 \\
FMA & 0.62 & 0.45 & 0.76 & 0.44 \\
\hline
\end{tabular}

in SPEArTC counts before and after a change in observational technology.

Figure 9 presents a time series of TC-frequency for SPEArTC using a 5-year running mean (for the entire SWP study region). Unlike Holland, who carried out a similar analysis on the early TC database (albeit on a subset of our study region), which resulted in an almost linear increase in TCs over time between 1915 and 1975 (as shown in Fig. 8b), Fig. 9 displays decadal to multidecadal variability in TC frequency. This variability might be explained by processes other than changes in observational technologies, given that regime shifts displayed do not correspond to known changes in observational technology. For example, El Niño Southern Oscillation (ENSO; Basher and Zheng, 1995) is known to influence the frequency of TCs in the SWP, whereby La Niña conditions result in heightened TC activity (15.3 TCs per season), compared with El Niño (15.0 TCs per season) (Diamond et al., 2013).
Using the MCC method (described in Sect. 4.3), Fig. 10 summarises the annual and seasonal MCC for SPEArTC according to three time periods of interest. It can be seen that pre-satellite era MCCs are situated (on average) further west than post-satellite and post-geostationary satellite era MCCs for all seasons. This apparent spatial modulation may be attributed to increased observational power towards the east of the study region (open water) in more recent years (i.e. a result of changing observational technology) or could be due to the influence of large-scale climate drivers (e.g. IPO or ENSO). To investigate the significance of the observed spatial variability, a number of simulations (200 in total) were produced to determine if the observed differences could be reproduced by statistics alone. This was achieved by first randomising the SPEArTC TC time series and then splitting the randomised time series into two groups (the first the same length as the pre-satellite era observations, the second the length of the post-satellite era). Figure 11 plots these simu- 


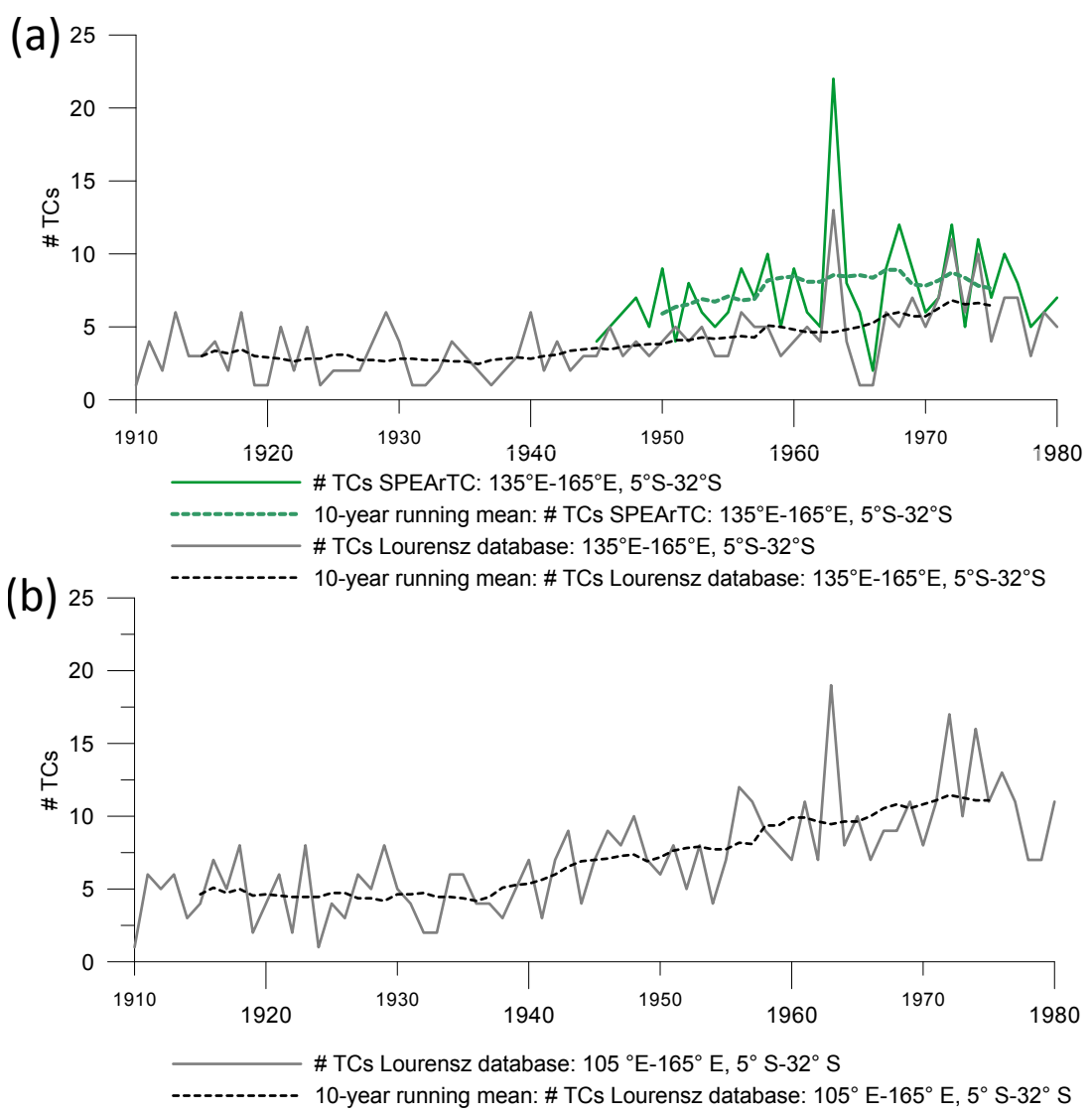

Figure 8. (a) Annual time series of TC counts for SPEArTC (1945-1980) and Lourensz (Lourensz, 1977, 1981; 1910-1980) database for

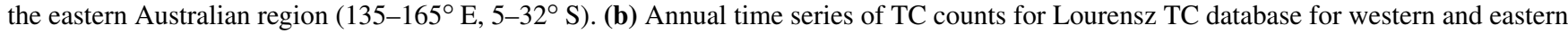
Australian regions $\left(105-165^{\circ} \mathrm{E}, 5-32^{\circ} \mathrm{S}\right)$. Solid lines indicate observed TC counts. Dashed lines represent 10-year running mean.

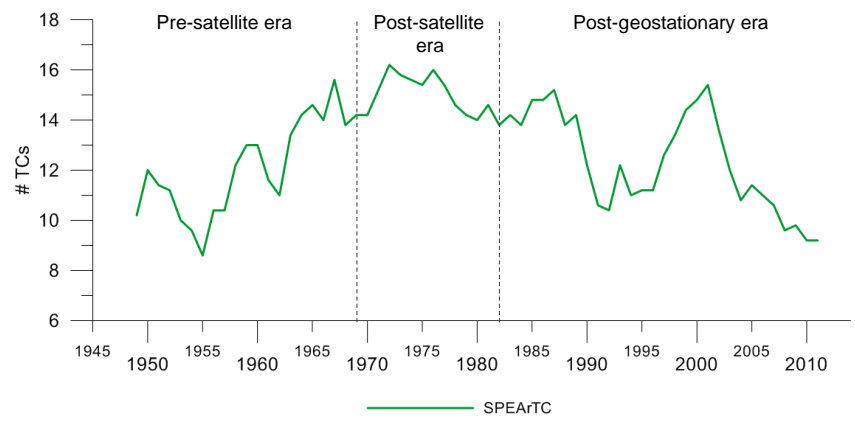

Figure 9. 5-year running mean time series of TC frequency for SPEArTC between 1945 and 2011.

lated mean centres of cyclogenesis (SMCC) with the original mean centres of cyclogenesis (MCC). The SMCC distribution lies within close proximity of the MCC, which indicates that the spatial modulation of SPEArTC MCCs may be statistical or related to chance (not significant) as opposed to any change in observational technology/climate driver.

\section{Conclusions}

This study provides a spatio-temporal intercomparison of three TC databases: JTWC, IBTrACS and SPEArTC for the SWP. Further, the study re-examines the impact of changing observational technologies on the quality of pre-satellite era data and compares the findings with Holland (1981) using the SPEArTC database from 1945. Although there is no doubting the numerous benefits in consolidating sources and creating a contemporary quality-controlled TC database, this study shows that considerable spatial and temporal variability exists between all TC databases studied here. As such, the choice of data set should be carefully considered, as it may influence the outcomes of subsequent analyses. It is suggested that the SPEArTC database is the most complete repository for the SWP, based on an intercomparison of TC events with the other BT products and the cross comparison using reanalysis data. Importantly, this analysis showed that environmental conditions were suited for cyclogenesis for a number of events listed only in the SPEArTC database. Further validation could determine if this is the case for all unique events listed in the SPEArTC database. 

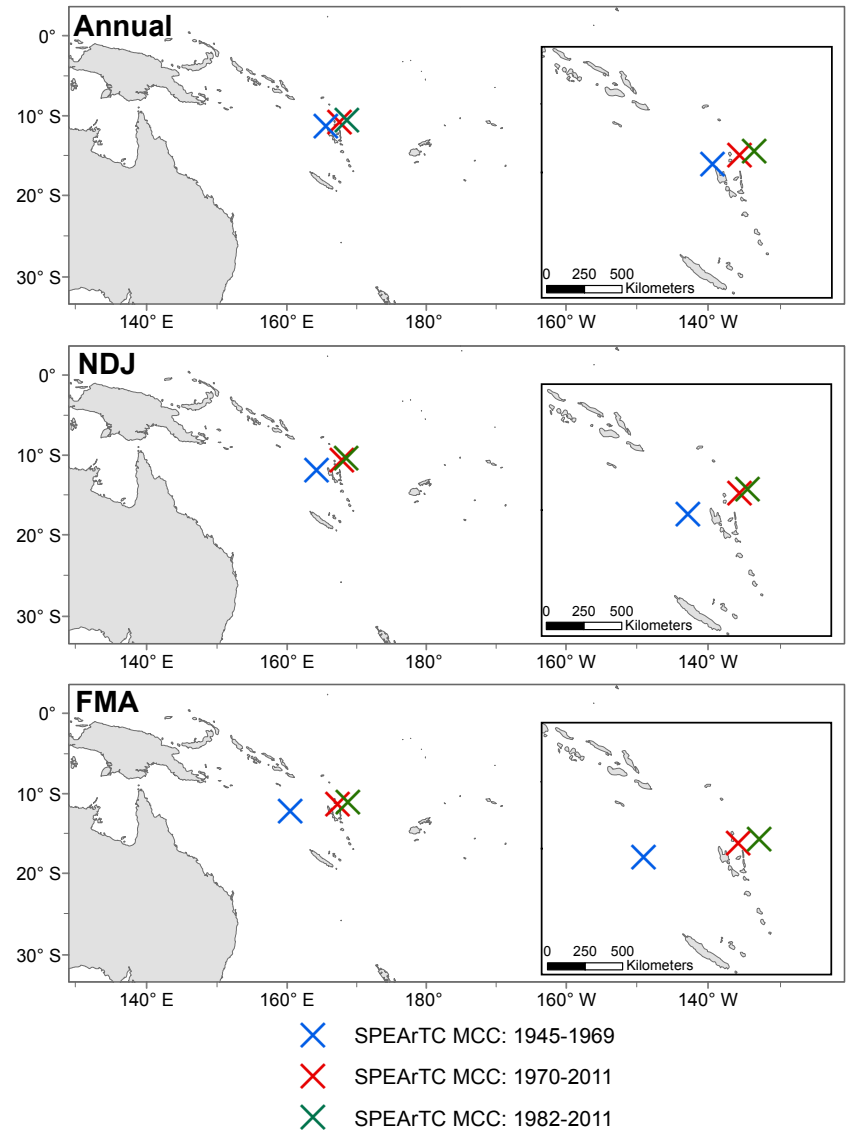

Figure 10. Annual and seasonal summary of the mean centre of cyclogenesis (MCC) for SPEArTC during pre-satellite era (19451969), post-satellite era (1970-2011) and post-geostationary satellite era (1982-2011). Inset maps provide a magnified summary of MCC locations.

The potential influence of changing observational technologies on the reliability of the SPEArTC database (TC counts) was investigated. Given the significant improvements in observational technologies, there is no doubt that our ability to detect and monitor TCs have improved with time. However, multiple lines of evidence (temporal, statistical and spatial analyses), revealed that the impact of the satellite (1969) and the geostationary satellite (1982) eras on the quality of the SPEArTC database is not as significant as initially suggested (Holland, 1981). In particular, our spatio-temporal analysis of pre-satellite, post-satellite and post-geostationary satellite TC observations confirm that SPEArTC does not suffer from the same positive trend in TC counts after the satellite era as did the earlier database used by Holland (1981). Time series analyses also showed that observed temporal trends in the TC time series do not correlate with the introduction of observational technologies and there is no statistical evidence of a change in TC counts between the time periods associated with changes in observational technology. The compilation of numerous sources in the construction of

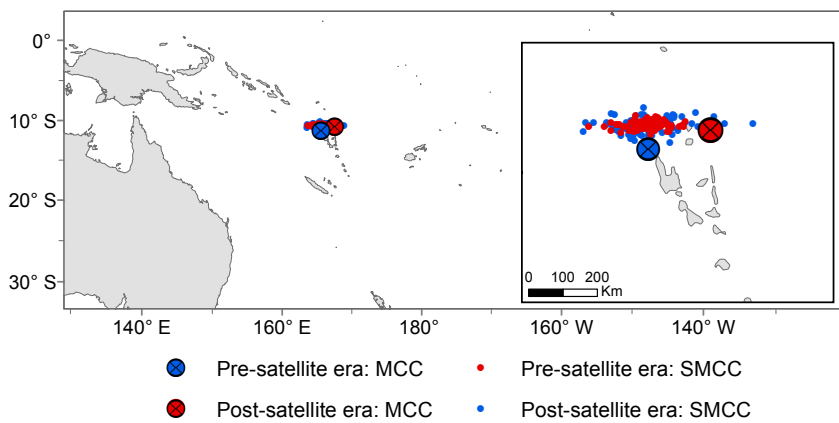

Figure 11. Comparison of pre-satellite (blue) and post-satellite (red) MCC for SPEArTC. Blue and red points indicate the mean centre of cyclogenesis (MCC) for 200 random simulations of preand post-satellite era TCs.

the more contemporary databases has no doubt improved their temporal consistency. A study assessing the quality of the National Hurricane Centers Hurricane Databases (HURDAT) North Atlantic TC database (Chang and Guo, 2007) estimates that up to one non-landfalling TC per year may be missing from pre-satellite TC records (1920-1965). Similarly, our study does not suggest that all SWP pre-satellite era TCs (1945-1969) are accounted for; rather that the introduction of the satellite era has not caused a significant change in TC counts for the SPEArTC database. As such, pre-satellite SPEArTC data (from 1945) may be used for certain applications (e.g. climatological studies of TC counts and TC genesis). It is important to note that studies of TC intensity from the pre-satellite and pre-geostationary satellite eras should be treated with caution due to the lack of reliable intensity estimates prior to this time (Dvorak, 1984; Klotzbach, 2006).

Our analysis also highlighted a shift in the MCC of TCs, with pre-satellite era TCs situated further west in the SWP and post-geostationary satellite TCs situated further east. Given the pre-satellite (1945-1969) and post-satellite eras (1970-2011) overlap somewhat with IPO negative (19461977) and IPO positive (1978-1998) conditions, changes in environmental conditions consistent with these phases may be responsible for this observed spatial modulation (Grant and Walsh, 2001). Therefore, further work will look at the relationship between phases of the IPO and TC activity in the SWP region, which will be made possible through the use of the extended TC database. 


\section{Data availability}

The following databases were used in this analysis:

- JTWC http://www.usno.navy.mil/NOOC/nmfc-ph/ RSS/jtwc/best_tracks/index.html (Chu et al., 2002)

- IBTrACS (v03r06: http://www.ncdc.noaa.gov/ibtracs/ 50index.php?name=ibtracs-data) (Knapp et al., 2010)

- SPEArTC (data set updated 28 January 2014: http: //apdrc.soest.hawaii.edu/projects/speartc) (Diamond et al., 2012).

- Lourensz TC Database - digitised from Lourensz (1977, 1981)

- Callaghan and Power Landfalling TC databases - digitised from Callaghan and Power (2011).

\section{The Supplement related to this article is available online at doi:10.5194/nhess-16-1431-2016-supplement.}

Acknowledgements. A. Magee was supported by a University of Newcastle International Postgraduate Research Scholarship (UNIPRS) and Research Scholarship Central (UNRSC50:50) Research Higher Degree (RHD) scholarship. This work was conducted as part of the Eastern Seaboard Climate Change Initiative (ESCCI) which received financial and/or in-kind support from the Australian Research Council (Linkage Grant LP120200494), the NSW Office of Environment and Heritage, Sydney Catchment Authority, Hunter Water Corporation, NSW Office of Water, NSW Environmental Trust and the NSW Department of Finance and Services. Financial assistance was also provided via a Postgraduate scholarship from the Commonwealth Scientific and Industrial Research Organisation (CSIRO). The authors would also like to thank Olivier Rey-Lescure at the University of Newcastle for technical assistance with spatial analysis and mapping, and Kim Colyvas from the Statistical Support Service at the University of Newcastle for his assistance with the GLMM modelling and the Asia Pacific Data Research Center at the University of Hawaii for access to NOAA's 20th Century Reanalysis data.

Edited by: R. Trigo

Reviewed by: two anonymous referees

\section{References}

Basher, R. and Zheng, X.: Tropical Cyclones in the Southwest Pacific: Spatial Patterns and Relationships to Southern Oscillation and Sea Surface Temperature, J. Climate, 8, 1249-1260, 1995.

Callaghan, J. and Power, S. B.: Variability and decline in the number of severe tropical cyclones making land-fall over eastern Australia since the late nineteenth century, Clim. Dynam., 37, 647662, doi:10.1007/s00382-010-0883-2, 2011.
Chand, S. S. and Walsh, K. J. E.: Tropical Cyclone Activity in the Fiji Region: Spatial Patterns and Relationship to Large-Scale Circulation, J. Climate, 22, 3877-3893, doi:10.1175/2009JCLI2880.1, 2009.

Chand, S. S. and Walsh, K. J. E.: The Influence of the MaddenJulian Oscillation on Tropical Cyclone Activity in the Fiji Region, J. Climate, 23, 868-886, doi:10.1175/2009JCLI3316.1, 2010.

Chand, S. S., McBride, J. L., Tory, K. J., Wheeler, M. C., and Walsh, K. J. E.: Impact of Different ENSO Regimes on Southwest Pacific Tropical Cyclones, J. Climate, 26, 600-608, doi:10.1175/JCLI-D-12-00114.1, 2013.

Chang, E. K. M. and Guo, Y.: Is the number of North Atlantic tropical cyclones significantly underestimated prior to the availability of satellite observations?, Geophys. Res. Lett., 34, L14801, doi:10.1029/2007gl030169, 2007.

Chu, J. H., Sampson, C. R., Levine, A. S., and Fukada, E. The Joint Typhoon Warning Centre Tropical Cyclone BestTracks, 1945-2000, available at: http://www.usno.navy.mil/ NOOC/nmfc-ph/RSS/jtwc/best_tracks/TC_bt_report.html (last access: 8 May 2015), 2002.

Coleman, F.: Frequencies, Tracks and Intensities of Tropical Cyclones in the Australian Region November 1909 to June 1969, Commonwealth Bureau of Meteorology, Canberra, Australia, 99 pp., 1971

Compo, G. P., Whitaker, J. S., Sardeshmukh, P. D., Matsui, N., Allan, R. J., Yin, X., Gleason, B. E., Vose, R. S., Rutledge, G., Bessemoulin, P. and Brönnimann, S.: The Twentieth Century Reanalysis Project, Q. J. Roy. Meteor. Soc., 137, 1-28, doi:10.1002/qj.776, 2011.

Diamond, H. J. and Renwick, J. A.: The climatological relationship between tropical cyclones in the southwest pacific and the madden-julian oscillation, Int. J. Climatol., 35, 676-686, doi:10.1002/joc.4012, 2015a.

Diamond, H. J. and Renwick, J. A.: The climatological relationship between tropical cyclones in the southwest Pacific and the southern annular mode, Int. J. Climatol., 35, 613-623, doi:10.1002/joc.4007, 2015b.

Diamond, H. J., Lorrey, A. M., Knapp, K. R., and Levinson, D. H.: Development of an enhanced tropical cyclone tracks database for the southwest Pacific from 1840 to 2010, Int. J. Climatol., 32, 2240-2250, doi:10.1002/joc.2412, 2012.

Diamond, H. J., Lorrey, A. M., and Renwick, J. A.: A Southwest Pacific Tropical Cyclone Climatology and Linkages to the El NiñoSouthern Oscillation, J. Climate, 26, 3-25, doi:10.1175/JCLI-D12-00077.1, 2013

Dowdy, A. and Kuleshov, Y.: An analysis of tropical cyclone occurrence in the Southern Hemisphere derived from a new satellite-era data set, Int. J. Remote Sens., 33, 7382-7397, doi:10.1080/01431161.2012.685986, 2012.

Dowdy, A. J.: Long-term changes in Australian tropical cyclone numbers, Atmos. Sci. Lett., 15, 292-298, doi:10.1002/as12.502, 2014.

Dowdy, A. J., Qi, L., Jones, D., Ramsay, H., Fawcett, R., and Kuleshov, Y.: Tropical Cyclone Climatology of the South Pacific Ocean and Its Relationship to El Niño-Southern Oscillation, J. Climate, 25, 6108-6122, doi:10.1175/JCLI-D-11-00647.1, 2012. 
Dvorak, V. F.: Tropical Cyclone Intensity Analysis Using Satellite Data, US Dep. Commer. Natl. Ocean. Atmos. Adm. Natl. Environ. Satell. Data, Inf. Serv., 47 pp., 1984.

Giovannelli, P. J.: Les Cyclones Tropicaux en Nouvelle-Caledonia, au Cours d'un Siecle (1852-1951), Noumea, New Caledonia, 25 pp., 1952.

Goebbert, K. and Leslie, L.: Interannual variability of Northwest Australian tropical cyclones, J. Climate, 23, 4538-4555, doi:10.1175/2010JCLI3362.1, 2010.

Grant, A. and Walsh, K.: Interdecadal variability in north-east Australian tropical cyclone formation, Atmos. Sci. Lett., 2, 9-17, doi:10.1006/asle.2001.0029, 2001.

Gray, W.: Global view of the origin of tropical disturbances and storms, Mon. Weather Rev., 96, 669-699, 1968.

Guard, C. P., Carr, L. E., Wells, F. H., Jeffries, R. A., Gural, N. D., and Edson, D. K.: Joint Typhoon Warning Center and the Challenges of Multibasin Tropical Cyclone Forecasting, Weather Forecast., 7, 328-352, doi:10.1175/1520-0434, 1992.

Harper, B. A., Stroud, S. A., Mccormack, M., and West, S.: A review of historical tropical cyclone intensity in northwestern Australia and implications for climate change trend analysis, Aust. Met. Mag, 57, 121-141, 2008.

Henderson-Sellers, A., Zhang, H., Berz, G., Emanuel, K., Gray, W., and Landsea, C.: Tropical Cyclones and Global Climate Change?: A Post-IPCC Assessment, 19-38, 1998.

Holland, G.: On the quality of the Australian tropical cyclone data base, Aust. Met. Mag, 29, 169-181, 1981.

Kerr, I. S.: Tropical Storms and Hurricanes in the Southwest Pacific, November 1939 to April 1969, New Zealand Ministry of Transport, 114 pp., 1976.

Klotzbach, P. J.: Trends in global tropical cyclone activity over the past twenty years (1986-2005), Geophys. Res. Lett., 33, doi:10.1029/2006GL025881, 2006.

Knapp, K. and Kossin, J.: New global tropical cyclone data set from ISCCP B1 geostationary satellite observations, J. Appl. Remote Sens., 1, 1-6, 2007.

Knapp, K. R. and Kruk, M. C.: Quantifying Interagency Differences in Tropical Cyclone Best-Track Wind Speed Estimates, Mon. Weather Rev., 138, 1459-1473, doi:10.1175/2009MWR3123.1, 2010.

Knapp, K. R., Kruk, M. C., Levinson, D. H., and Gibney, E. J.: Archive Compiles New Resource for Global Tropical Cyclone Research, Eos Trans. AGU, 90, 46-46, doi:10.1029/2009EO060002, 2009.

Knapp, K. R., Kruk, M. C., Levinson, D. H., Diamond, H. J., and Neumann, C. J.: The International Best Track Archive for Climate Stewardship (IBTrACS), B. Am. Meteorol. Soc., 91, 363376, doi:10.1175/2009BAMS2755.1, 2010.

Kossin, J. P., Emanuel, K. A., and Vecchi, G. A.: The poleward migration of the location of tropical cyclone maximum intensity. Nature, 509, 349-352, doi:10.1038/nature13278, 2014.

Kruk, M., Knapp, K., and Levinson, D.: A technique for combining global tropical cyclone best track data, J. Atmos. Ocean. Technol., 27, 680-692, doi:10.1175/2009JTECHA1267.1, 2010.

Kuleshov, Y.: Southern Hemisphere Tropical Cyclone Climatology, Modern Climatology, edited by: Wang, S.-Y., inTech, available at: http://www.intechopen.com/books/modern-climatology/ southern-hemisphere-tropical-cyclone-climatology (last access: 20 October 2015), doi:10.5772/35080, 2002.
Kuleshov, Y., Qi, L., Fawcett, R., and Jones, D.: On tropical cyclone activity in the Southern Hemisphere: Trends and the ENSO connection, Geophys. Res. Lett., 35, L14S08, doi:10.1029/2007GL032983, 2008.

Kuleshov, Y., Qi, L., Jones, D., Fawcett, R., McBride, J., and Ramsay, H.: On Developing a Tropical Cyclone Archive and Climatology for the South Indian and South Pacific Oceans, Indian Ocean Tropical Cyclones and Climate Change, edited by: Charabi, Y., Springer Netherlands, Dordrecht, 189-197 doi:10.1007/978-90-481-3109-9, 2010.

Liu, K. S. and Chan, J. C. L.: Interannual variation of Southern Hemisphere tropical cyclone activity and seasonal forecast of tropical cyclone number in the Australian region, Int. J. Climatol., 32, 190-202, doi:10.1002/joc.2259, 2010.

Lourensz, R. S.: Tropical Cyclones in the Australian region July 1909 to June 1975, Melbourne, 111 pp., 1977.

Lourensz, R. S.: Tropical Cyclones in the Australian region: July 1909 to June 1980, Melbourne, 94 pp., 1981.

Mann, H. B. and Whitney, D. R.: On a Test of Whether one of Two Random Variables is Stochastically Larger than the Other, Ann. Math. Stat., 18, 50-60, doi:10.1214/aoms/1177730491, 1947.

McBride, J. L. and Zehr, R.: Observational Analysis of Tropical Cyclone Formation. Part II: Comparison of Non-Developing versus Developing Systems, J. Atmos. Sci., 38, 1132-1151, doi:10.1175/1520-0469(1981)038<1132:OAOTCF>2.0.CO;2, 1981.

McCulloch, C. E. and Neuhaus, J. M.: Generalized linear mixed models, John Wiley \& Sons, Ltd., 2001.

Nicholls, N., Landsea, C., and Gill, J.: Recent trends in Australian region tropical cyclone activity. Meteorol. Atmos. Phys., 205, 197-205, 1998.

Nolan, D. S. and McGauley, M. G.: Tropical cyclogenesis in wind shear: Climatological relationships and physical processes, Cyclones: Formation, Triggers, and Control, 1-36, 2012.

Paterson, L. A., Hanstrum, B. N., Davidson, N. E., and Weber, H. C.: Influence of Environmental Vertical Wind Shear on the Intensity of Hurricane-Strength Tropical Cyclones in the Australian Region, Mon. Weather Rev., 133, 3644-3660, doi:10.1175/MWR3041.1, 2005.

Ramsay, H. A., Camargo, S. J., and Kim, D.: Cluster analysis of tropical cyclone tracks in the Southern Hemisphere, Clim. Dynam., 39, 897-917, doi:10.1007/s00382-011-1225-8, 2011.

Revell, G. C.: Tropical Cyclones in the Southwest Pacific, November 1969 to April 1979, New Zeal. Minist. Transp. Wellington, New Zeal., NZMS Misc., 53, 1981.

Sabbatelli, T. A. and Mann, M. E.: The influence of climate state variables on Atlantic Tropical Cyclone occurrence rates, J. Geophys. Res.-Atmos., 112, 1-8, doi:10.1029/2007JD008385, 2007.

Sampson, C. R. and Schrader, A. J.: The Automated Tropical Cyclone Forecasting System (Version 3.2), B. Am. Meteorol. Soc, 81, 1231-1240, 2000.

Schreck, C. J., Knapp, K. R., and Kossin, J. P.: The Impact of Best Track Discrepancies on Global Tropical Cyclone Climatologies using IBTrACS, Mon. Weather Rev., 142, 3881-3899, doi:10.1175/MWR-D-14-00021.1, 2014.

Terry, J. P.: Tropical Cyclones: Climatology and Impacts in the South Pacific, Springer, New York, 2007.

Trewin, B.: An enhanced tropical cyclone data set for the Australian region. 20th Conf. Clim. Var. Chang., available at: https://ams. 
confex.com/ams/88Annual/techprogram/paper_128054.htm (last access: 31 January 2015), 2008.

Visher, S.: Tropical Cyclones of the Pacific, Bulletin 20, Honolulu, Bernice P. Bishop Museum, 163 pp., 1925.

Webster, P. J., Holland, G. J., Curry, J. A., and Chang, H.R.: Changes in tropical cyclone number, duration, and intensity in a warming environment, Science, 309, 1844-1846, doi:10.1126/science.1116448, 2005.
Wijnands, J. S., Shelton, K., and Kuleshov, Y., : Improving the Operational Methodology of Tropical Cyclone Seasonal Prediction in the Australian and the South Pacific Ocean Regions, Adv. Meteorol., 2014, 1-8, doi:10.1155/2014/838746, 2014.

Wu, L., Wang, C., and Wang, B.: Westward Shift of Western North Pacific Tropical Cyclogenesis, Geophys. Res. Lett., 42, 15371542, doi:10.1002/2015GL063450, 2015. 